\title{
A estrutura de impacto do Cerro do Jarau, Quaraí, RS
}

\author{
Ruy Paulo Philipp ${ }^{1}$, Silvia Beatriz Alves Rolim ${ }^{2}$, Carlos Augusto Sommer ${ }^{1,2}$, \\ Carlos Roberto de Souza Filho ${ }^{3}$ \& Nelson Amoretti Lisboa ${ }^{2}$
}

\begin{abstract}
Resumo O Cerro do Jarau está localizado na região de Quarai, porção sudoeste do RS e representa um dos raros astroblemas encontrados na região sul. A estrutura apresenta forma circular e estruturalmente complexa, medindo cerca de 14 quilômetros de diâmetro. O núcleo central da estrutura está soerguido e tem forma circular com 7 quilômetros de diâmetro, com desníveis de cerca de 160 metros entre as porções mais elevadas de sua borda até os níveis mais profundos da sua porção externa. A feição circular exibida por esta estrutura é composta por um conjunto morfológico de anéis concêntricos constituídos por depressões topográficas nas áreas externas e central, separadas na porção centro-norte da estrutura por uma crista soerguida em forma de meia lua. Estas feições são remanescentes do processo erosivo de uma cratera de impacto gerada pela colisão de um corpo celeste de grandes dimensões. Os efeitos do impacto sob as rochas sedimentares da Formação Botucatu e basálticas da Formação Serra Geral originou um conjunto de zonas de falhas normais e zonas de cisalhamento rúpteis, além do soerguimento estrutural dos arenitos eólicos na porção central. As feições indicativas do metamorfismo de impacto são brechas de impacto, brechas de injeção e arenitos e basaltos impactados, com formação de feições de deformação planares em quartzo, feldspatos e piroxênios. A partir das rochas afetadas podemos indicar que a geração da cratera é de idade pós-Cretáceo. A ocorrência dominante de feições petrográficas (PDFs e PFs) e de cones de estilhaçamento, e as raros afloramentos com rochas geradas pelo impacto são indicativos do alto grau de exumação da cratera.
\end{abstract}

Palavras-chave: Astroblema, cratera de impacto, metamorfismo de impacto, Estrutura do Cerro do Jarau.

\begin{abstract}
The impact structure of the Cerro do Jarau, Quarai, RS, southern Brazil. The Cerro do Jarau is located in Quaraí region, in the southwestern portion of the RS state and represent one of the rare astrobleme of the south region of Brazil. The structure presents circular and structurally complex form, with a diameter of approximately $14 \mathrm{~km}$. The central core of the structure is uplifted and has around shape with $7 \mathrm{~km}$ of diameter, with steep-topographic gradients of up to 160 meters between the high portions of its edge until the levels more deep in the external portion. The circular features showed by its structure is compound by a morphological group of concentric rings, constituted by topographic depressions in the external and central areas, separated in the north and central portion of the structure by an elongated topographic elevation in half moon shape. These features are reminiscent of weathering and erosive process of an impact crater generated by collision of a meteoritic body of large dimensions. These impact effects under the sandstones of Botucatu Formation (Triassic-Jurassic) and basaltic lava flows of Serra Geral Formation (Jurassic-Cretaceous) generated a group of extensional normal faults and transcurrent ruptile shear zones moreover the structural uplift of the sedimentary rocks in central portion of the Cerro do Jarau structure. The observed features of impact metamorphism are PDF's and PF's structures in quartz and plagioclase of impacted sandstones and basalts, as well, probably and rare impact breccias and injection breccias. The circular shape seems today to represent the weathering and erosion remnants of the original crater.
\end{abstract}

Keywords: astrobleme, impact crater,impact metamorphism, Cerro do Jarau Structure.

INTRODUÇÃO A observação de estruturas circulares, inicialmente em fotografias áreas, posteriormente em imagens de radar e satélite, sempre despertou a curiosidade de pesquisadores e profissionais das geociências. Ao longo da evolução do conhecimento geológico a presença de tais estruturas tem sido atribuída a processos diversos, estendendo-se desde corpos ígneos até o impacto de meteoritos. Entre as intrusões destacam-se as chaminés, plugs e/ou necks de lamproítos e kimberlitos, portadores ou não de diamantes, intrusões máficas-ultramáficas alcalinas, com seus depósitos de fosfatos e de $\mathrm{Nb}$, caldeiras vulcânicas e outros corpos intrusivos vinculados a evento vulcânico intra-continental ou mesmo em áreas orogênicas, relacionadas ao período de subducção e/ou a etapa pós-colisional. Por outro lado, a geração de crateras de impacto relacionadas a queda de meteoritos, sempre fascinou os pesquisadores por sua origem cósmica ou como no caso da cratera Chixulub, no México, pela sua associação com a extinção dos dinossauros e outras formas de vida no

1 - UFRGS, Instituto de Geociências, Centro de Estudos em Petrologia e Geoquímica, Porto Alegre (RS), Brasil. Pesquisador do CNPq. E-mail: ruy.philipp@ufrgs.br

2 - UFRGS, Instituto de Geociências, Departamento de Geodésia, Porto Alegre (RS), Brasil. E-mail: silvia.rolim@ufrgs.br: carlos.sommer@ufrgs.br; nelson.lisboa@ufrgs.br

3 - UNICAMP, DGRN-IG, Campinas (SP), Brasil. E-mail: beto@ige.unicamp.br 
limite do Cretáceo-Triássico.

Para avaliar as estruturas circulares identificadas nas imagens de satélite são realizados trabalhos integrados de mapeamento geológico e estrutural, análise petrográfica, geofísica, geoquímica e geocronologia. No Brasil são conhecidas estruturas circulares de maior porte como aquelas relacionadas a caldeiras Neoproterozóicas no sul do Brasil, (Sommer 1994; Lima 1995; Liz et al. 2004; Gastal et al. 2006), e um grande número de corpos menores, como as intrusões alcalinas de idade Terciária de Poços de Caldas, em MG (Slavec et al. 2004), de Lages, em SC (Scheibe et al. 2005), as Chaminés Fonolíticas do RS (Philipp et al. 2005) e o Pico do Cabugi (Ferreira \& Sial 2006). Destacam-se ainda no Terciário a ocorrência de lamproítos e kimberlitos, como aqueles relatados em MG por Leonardos et al. (1994), no MT por Weska et al. (2001) e Zolinger et al. (2002), no Rio Grande do Sul por Tedesco \& Robaina (1991) e Caldasso et al. (1994). Da mesma maneira tem sido descritos astroblemas ou crateras de impacto como o Domo de Araguainha, no limite dos estados de MT e GO (Crosta 2002), o Domo de Vargeão, em SC (Crosta et al. 2005) e o provável astroblema denominado Cratera de Colôniaem SP (Ricomini et al. 2005).

A estrutura circular do Cerro do Jarau está localizada na porção sul da Bacia do Paraná, no extremo SW do Rio Grande do Sul (Fig. 1). A estrutura possui uma forma concêntrica, possui cerca de $14 \mathrm{~km}$ de diâmetro e tem seus limites mais externos marcados pelo arroio Garupá ao norte, e o arroio Quaraí-Mirim e rio Quaraí, ao sul (Fig. 2). É constituída na sua porção central por rochas sedimentares de idade Jurássica, que estão cobertas nas porções mais externas por lavas básicas da Formação Serra Geral, de idade Mesozóica (Fig. 3). A porção central da estrutura tem forma circular e é composta por arenitos da Formação Botucatu. Este núcleo está soerguido, constituindo na sua porção norte relevo positivo marcado por cristas, gradando para as

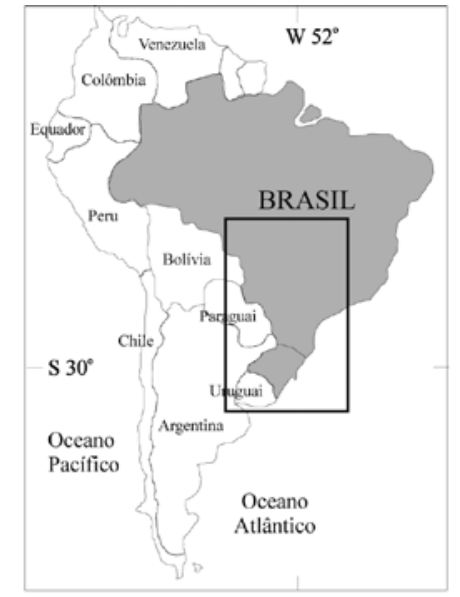

\section{Legenda}

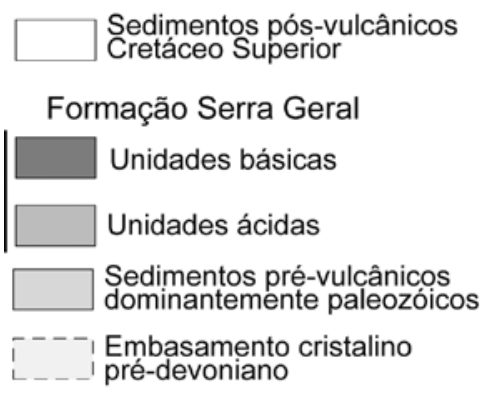

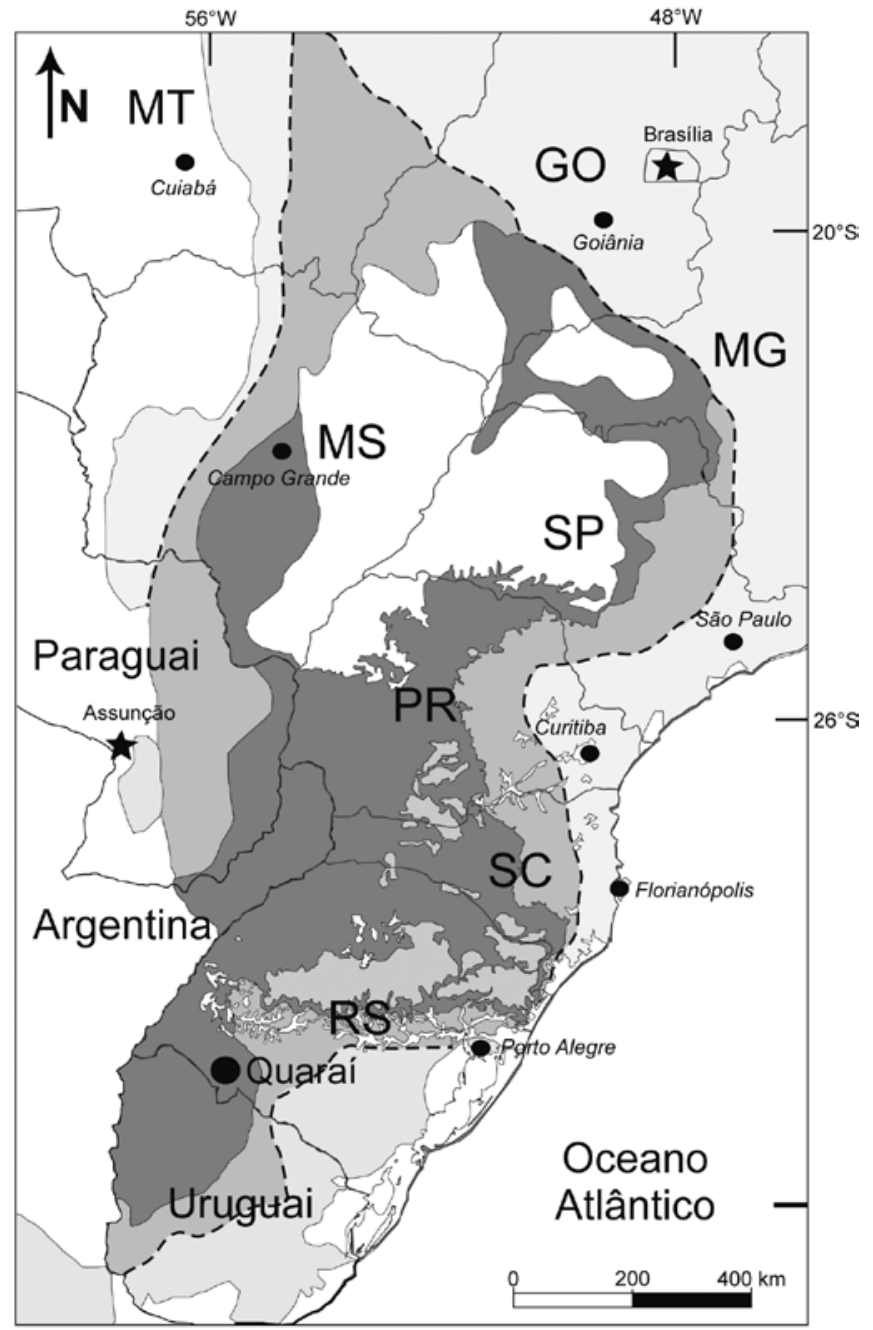

Figura 1 - Mapa geológico generalizado da Bacia do Paraná com localização da estrutura do Cerro do Jarau, na região de Quarai. 


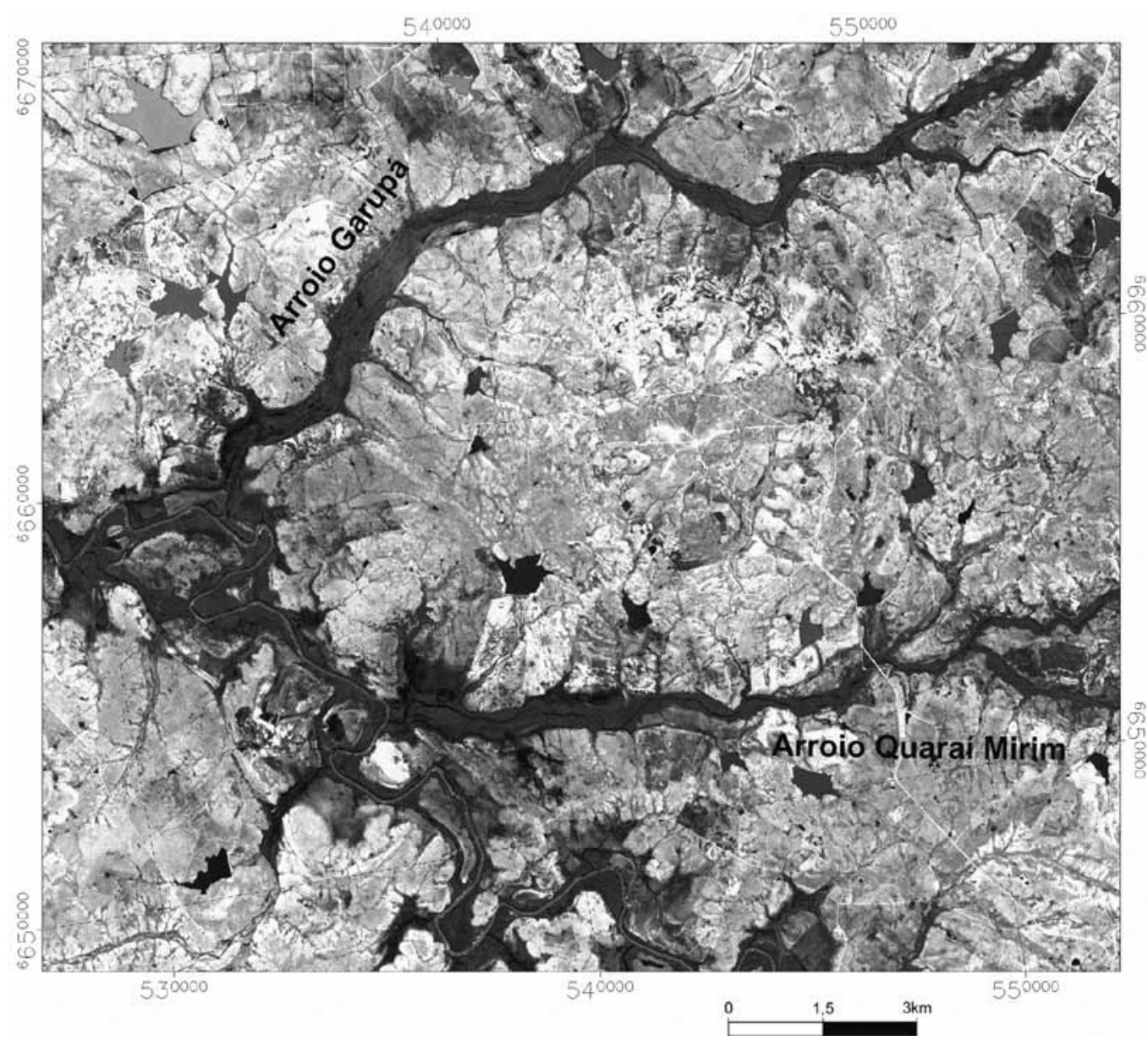

Figura 2 - Imagem de satélite (ASTER, bandas 2,1,3) destacando a estrutura circular do Cerro do Jarau, Quarai, RS, delimitada pelos arroios Garupá e Quarai Mirim.

áreas mais rebaixadas do centro e da porção sul (Figs. $4 \mathrm{a}, 4 \mathrm{~b})$. O contato entre as unidades é dominantemente por falha inversa. Na porção sudeste não é observado contato direto entre as unidades, mas observações de campo e microscópicas demonstram que as lavas basálticas mostram relações de contemporaneidade com os arenitos da Formação Botucatu.

A estrutura circular do Cerro do Jarau foi interpretada inicialmente como resultante da interação da intrusão de um corpo ígneo subvulcânico com estruturas tectônicas, e posteriormente, como uma cratera de impacto.

Este trabalho apresenta a integração dos resultados obtidos a partir de duas abordagens distintas e complementares, o mapeamento geológico-estrutural apoiado na petrografia e os levantamentos indiretos da geofísica (magnetometria e gravimetria). Os dados geofísicos estão sendo publicados separadamente (Rolim et al. 2010). A análise dos dados coletados no Cerro do Jarau pelo primeiro conjunto de informações indica que a estrutura circular pode ser interpretada como um astroblema. A origem da estrutura é complexa e polifásica e pode ser resultante da interação de fenômenos iniciados por um impacto de meteorito e pelo desenvolvimento posterior de um sistema principal de falhas rúpteis, ao qual podem estar associadas as intrusões de corpos básicos subvulcânicos identificados no campo.

MÉTODOS DE TRABALHO A estrutura do Cerro do Jarau foi observada através de fotografias aéreas nas escalas 1:110.000 e 1:60.000, imagens de radar e de satélite. As imagens de satélite foram do tipo ASTER (bandas 2,1,3). Foram analisadas a disposição e a intensidade da rede de drenagens, os contatos litológicos, a forma e distribuição das principais estruturas rúpteis como falhas e fraturas.

Os trabalhos de mapeamento geológico e estrutural permitiram o reconhecimento das litologias e das principais estruturas que caracterizam as rochas da estrutura. Foram descritos e amostrados cerca de 40 afloramentos, distribuídos nas porções internas, externas e ao longo das cristas localizadas na porção norte da estrutura. Os alvos dos trabalhos de campo foram previamente selecionados, a partir do processamento dos dados geofísicos e das imagens de satélite e fotografias aéreas. Os trabalhos de campo tiveram como base a carta topográfica Sanga Nhanduva (SH-21-ZA-I-2-SE), onde os afloramentos foram localizados e descritos com base no tipo de rocha, disposição de estruturas primárias e tectônicas. Foram realizados perfis geológicos através das principais estradas e arroios que 


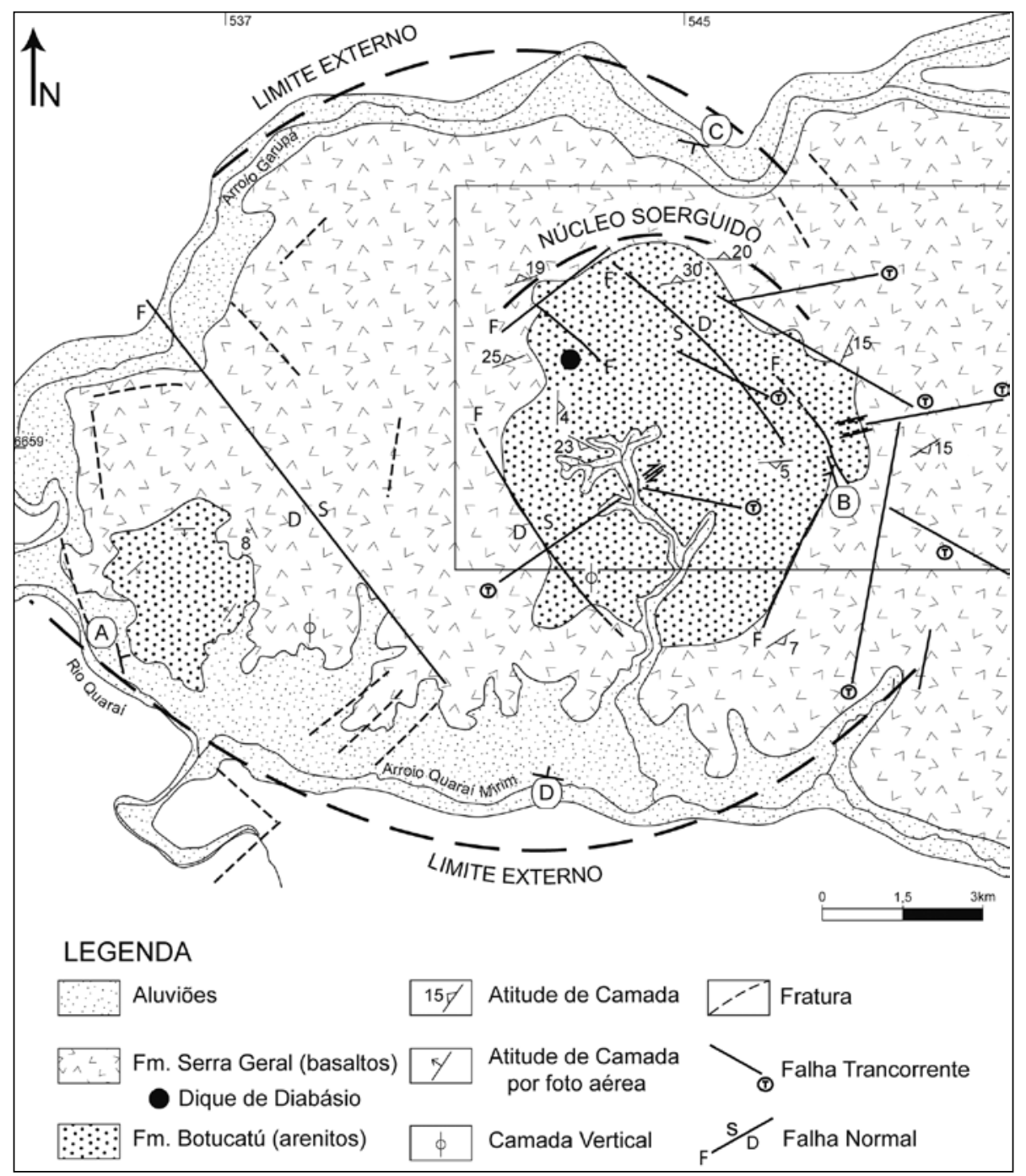

Figura 3 - Mapa geológico da região do Cerro do Jarau, Quarai, RS, localizando a área de levantamento estrutural. Modificado de Lisboa et al. 1987.

(A)

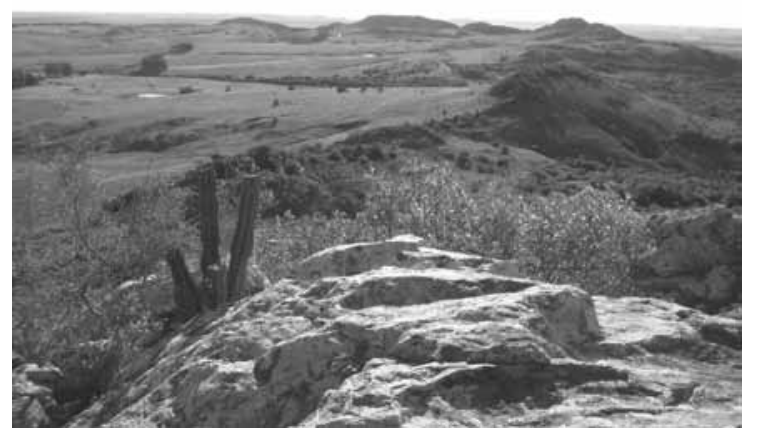

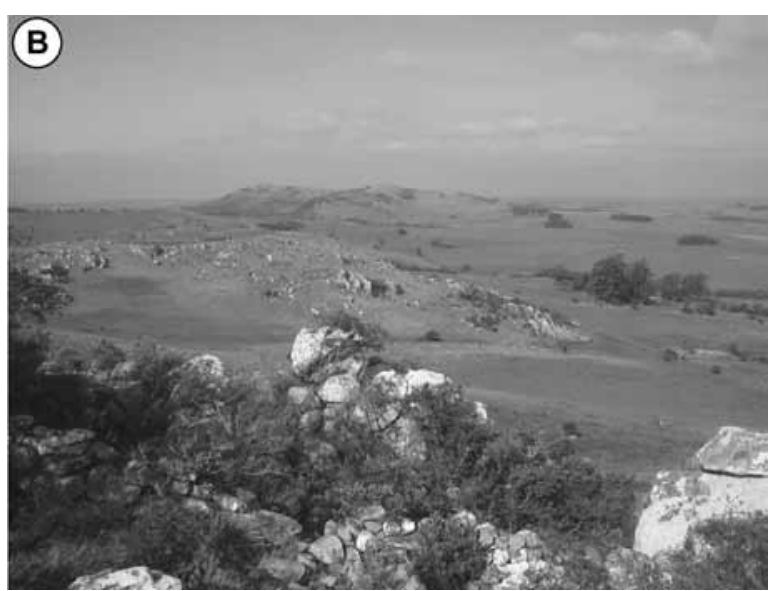

Figura 4 - Vista geral das cristas de arenito da Formação Botucatu da porção norte do núcleo soerguido do astroblema do Cerro do Jarau. (A) Ressaltando a morfologia curva da estrutura. Foto tirada no extremo nordeste da estrutura com vista para oeste. (B) Destaque para as cristas de arenito segmentadas por ação de zonas de cisalhamento rúpteis, que aparecem em destaque na porção centro-superior das figuras $4 A$ e $4 B$ como uma drenagem alinhada que segmenta as cristas de arenito. Foto tirada no extremo oeste da estrutura com vista para leste. 
seccionam a estrutura e o seu entorno, bem, como em toda a extensão de suas cristas.

Para análise macro e microscópica foram selecionadas 14 amostras de rochas areníticas e 06 amostras dos basaltos encaixantes. As lâminas delgadas foram descritas e fotografadas em microscópio petrográfico Leica modelo DMLP.

Durante os trabalhos de campo foram coletados dados estruturais relativos ao acamadamento plano-paralelo, marcado pelos limites de sets de um conjunto de estratificações cruzadas, além de fraturas, juntas, estrias de falha, espelho de falhas e zonas de cisalhamento direcionais de alto ângulo. Os dados coletados foram tratados no programa Stereonet e representados em diagramas de equiárea.

CONTEXTO GEOLÓGICO REGIONAL A estrutura circular do Cerro do Jarau foi identificada em fotografias aéreas por Grehs (1969), que observou anomalias circulares no padrão da rede de drenagens e na morfologia das rochas basálticas da região de Quaraí. A distribuição de forma elíptica das lavas ao redor do Cerro do Jarau levou o autor a considerar que os derrames se amoldaram a paleogeomorfologia. Os estudos de campo, entretanto, sugeriram que a feição geomorfológica do Cerro do Jarau é parte de um domo estrutural resultante do soerguimento pós-impacto situado temporalmente após o início do Cretáceo.

A vinculação da estrutura com esforços tectônicos foi caracterizada por Hausman (1966) que denominou esta estrutura como Horst do Jarau. A interpretação das novas imagens de radar pelo Projeto RADAMBRASIL, sintetizadas em Moreira et al. (1980) e, posteriormente, descritas em Horbach et al. (1986), destacaram novamente a estrutura do Jarau. Moreira et al. (1980) ressaltaram que a estrutura dômica do Cerro do Jarau está encaixada em falhamentos de direção noroeste, reativados através da intrusão de corpos subvulcânicos não aflorantes. Ressaltaram os autores que as rochas vulcânicas da Formação Serra Geral foram afetadas e soerguidas pelos movimentos tectônicos que originaram a estrutura e que são de idade pós-Mesozóica.

Schuck \& Lisboa (1987), reconheceram com base na interpretação das imagens de radar e de fotografias aéreas uma estrutura dômica nas cabeceiras do arroio Garupá (Domo das cabeceiras do Garupá) e uma estrutura menor reconhecida como Estrutura Falhada Anelar do Jarau, balizada por estruturas tectônicas direcionadas, respectivamente, segundo as direções NE e NW. Lisboa et al. (1987) salientam a indefinição quanto a origem da Estrutura Anelar Sinforme Falhada do Jarau, ressaltando que a mesma pode representar um astroblema. Em descrição detalhada da geologia e da geomorfologia da região do Cerro do Jarau, os autores destacam a origem da estrutura a partir da relação entre a diferenciação morfológica, diversidade litológica e estrutural e a ação do tempo. O controle estrutural da rede de drenagens e do relevo e a identificação de cataclasitos são relacionados com as estruturas tectônicas. A elevação topográfica dos arenitos do centro da estru- tura, colocando-os ao mesmo nível das rochas vulcânicas da Formação Serra Geral, é atribuída a ação de um sistema de falhas de direção noroeste-sudeste.

Estudos recentes desenvolvidos por Calbo (inédito) resultaram no levantamento geofísico detalhado do Cerro do Jarau através de magnetometria e gravimetria. Os resultados estão sintetizados e discutidos por Rolim et al. (2010) que constatou a presença de uma anomalia negativa no centro da estrutura, na bacia do arroio Nhanduvaí, com núcleo positivo muito pequeno relacionado a fontes magmáticas em sub-superfície e anomalias positivas correspondendo aos arenitos das cristas do núcleo soerguido. Esta afirmação esta baseada na ocorrência em campo de um dique de diabásio cortando os arenitos na porção noroeste da estrutura. Considerando-se que a assinatura típica de astroblemas são anomalias circulares magnéticas e gravimétricas negativas, podendo ou não conter anomalia positiva no centro, não se pode descartar a possibilidade que a gênese da morfoestrutura anelar do Cerro do Jarau seja devido ao impacto de um meteorito.

\section{GEOLOGIA DOS ARENITOS E DOS BASALTOS} DO CERRO DO JARAU Os levantamentos geológicos do Cerro do Jarau permitiram reconhecer duas unidades litoestratigráficas, além de depósitos aluviais recentes: Formações Botucatu e Serra Geral. As litologias encontradas ao longo de todo o núcleo soerguido da estrutura, tanto na sua porção alçada ao norte como na sua porção mais rebaixada e central, são caracterizadas por arenitos eólicos, enquanto que sua porção externa e envoltória é composta por derrames basálticos.

Formação Botucatu Os afloramentos de arenitos são abundantes, ocorrendo excelentes exposições nas cristas de porção norte da estrutura central e em parte de sua porção central (Figs. 4a, 4b). Os arenitos apresentam estruturas cruzadas de médio a grande porte que se apresentam truncadas por sets suborizontais com estruturas plano-paralelas marcando os antigos níveis de base (Fig. 5a). As camadas possuem espessuras milimétricas a centimétricas, mostram estrutura maciça e estão caracterizadas pela alternância de níveis com pequena diferença de tamanho dos grãos e, mais raramente, por níveis ricos em minerais opacos.

Os arenitos apresentam cor esbranquiçada, cinza clara e rosada, textura arenosa, com granulação fina a média e predominância de grãos foscos com forma arredondada a subarredondada e elevado grau de seleção (Fig. 5b). Composicionalmente são classificados como arcóseos, com uma mineralogia dominada por quartzo, com proporção variável entre 5 e $15 \%$ de feldspatos, e subordinadamente, minerais opacos, zircão, rutilo e raros litoclastos de rochas vulcânicas de composição básica. Os feldspatos do tipo microclínio são predominantes, possui formas subarredondadas, geminação tipo Ab-Periclíneo e mostram-se límpidos (Fig. 5c). O plagioclásio ocorre em proporções subordinadas, mostra forma subarredondada e aspecto sujo, definido pela presença de finos agregados de sericita e/ou argilo-minerais. A coloração rosada está relacionada a percola- 

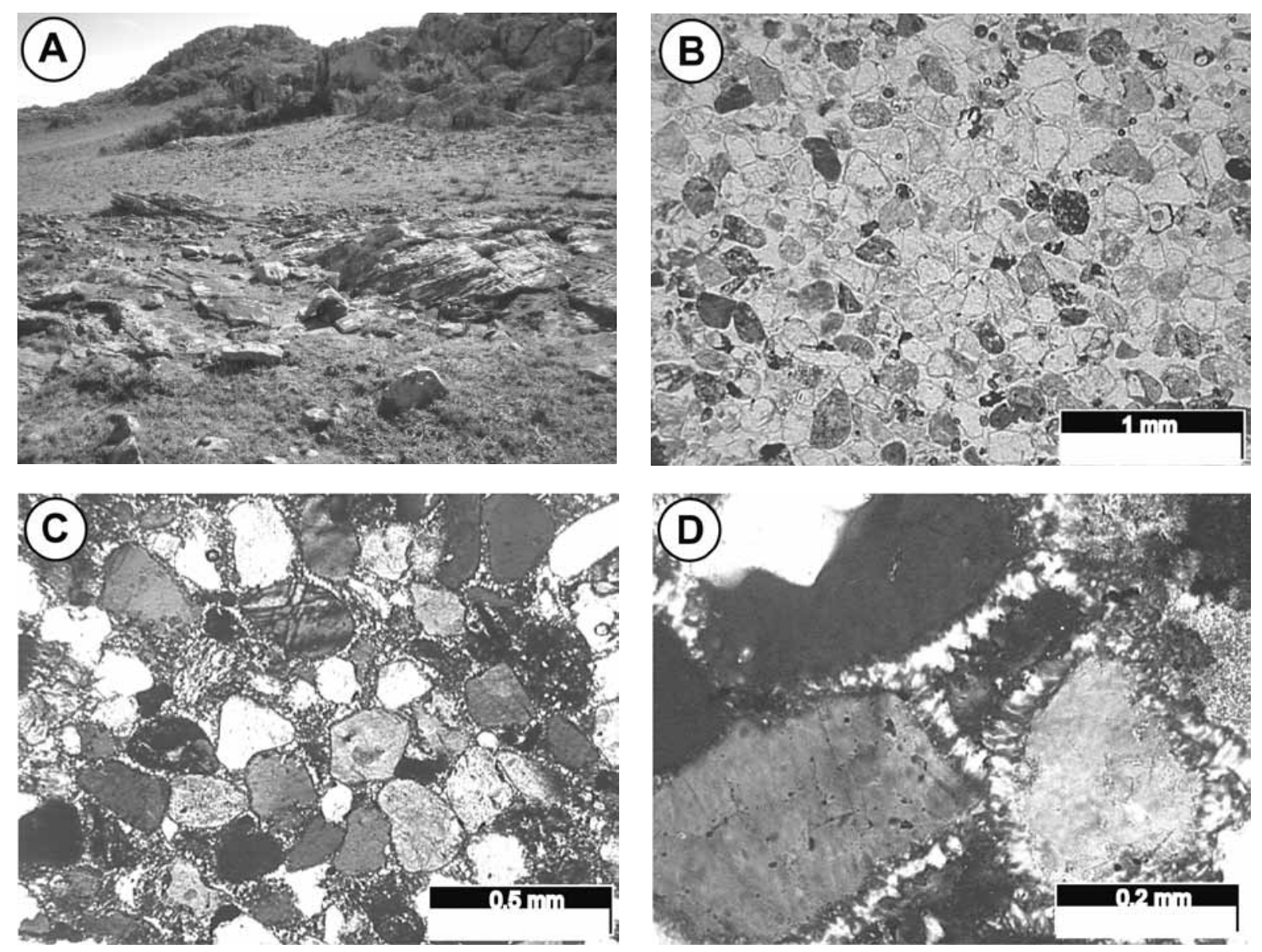

Figura 5 - Aspectos macro e microscópios dos arenitos do núcleo da estrutura. (A) Vista de afloramento de arenito da Formação Botucatu na porção centro-norte da estrutura destacando a estratificação cruzada de grande porte. (B) Aspecto geral dos arenitos ao microscópio petrográfico destacando os grãos argilizados de feldspato e pequenos litoclastos escuros de basalto (luz natural, aumento 2.5x), C) Aspecto geral do arenito em luz polarizada ressaltando o arcabouço e o baixo percentual de matriz quartzosa (aumento 5x), D) Detalhe do crescimento epitaxial do cimento quartzoso do tipo calcedônia, (luz polarizada, aumento 20x).

ção de hidróxidos de ferro, oriundos da decomposição de litoclastos de rochas vulcânicas alterados.

Os grãos estão envoltos inicialmente por uma fina camada de cimento de óxido de ferro, caracterizada na difratometria de raios X como hematita. Sobre esta película ocorre um significativo crescimento de cimento de calcedônia definido pela formação de agregados epitaxiais, com forma alongada disposta perpendicular ao limite dos grãos do arcabouço (Fig. 5d). De modo restrito, o cimento é composto por agregados de finos cristais de quartzo. Não há porosidade secundária. A ampla maioria dos grãos está envolta por cimento de calcedônia, não apresentando contatos diretos, indicando que as transformações ocorreram em nível crustal raso e sobre baixo grau de compactação.

A cimentação é responsável pela alta coesão da rocha. Nas proximidades da zona de falhas extensional de direção $\mathrm{N}^{\circ} 0^{\circ} \mathrm{E}$ e do dique de diabásio que estão situados no extremo noroeste da estrutura, o arenito mostrou sua coesão mais elevada.

As feições petrográficas (estrutura, textura e composição mineralógica) observadas nos arenitos são semelhantes àquelas encontradas nos arenitos da Formação Botucatu que afloram na região de Taquara e Gravataí, descritas por Morris (1963), e também com as observações feitas por Scherer (1998) e Scherer \& Lavina (2006) para a região oeste do RS. Entre as principais feições destacam-se a estratificação cruzada de grande porte, a granulação grossa a média, os grãos foscos, o caráter bimodal, o elevado grau de seleção e arredondamento, a composição mineral rica em quartzo, presença notável de feldspatos, ocorrência comum de cimento silicoso e coesão média a elevada. Com relação ao aumento da coesão dos arenitos, Morris (1963) associa esta feição a proximidade com sills e diques de rochas básicas da Formação Serra Geral.

A disposição original das estruturas sedimentares dos arenitos da porção central da estrutura foi obtida através da orientação das estruturas plano-paralelas, que comumente marcam os limites entre os sets dos estratos cruzados. Nas áreas pouco deformadas, o acamadamento primário apresenta direção nordeste, com 
mergulhos suaves, entre 4 e $8^{\circ}$ para SE e NW (Fig. 6).

$\mathrm{Na}$ maior parte do núcleo central da estrutura os arenitos apresentam elevado grau de fraturamento, com fraturas de disposição irregular e espaçamentos na escala centimétrica. Nas cristas da porção norte da estrutura, parte das fraturas estão preenchidas por veios de quartzo de cor branca e espessuras entre 2 a $15 \mathrm{~mm}$. Os limites das fraturas são retilíneos a pouco curvilíneos.

Na parte leste do núcleo central, os arenitos estão muito deformados e são observadas brechas e/ou cataclasitos, caracterizadas por fragmentos de arenitos com formas irregulares, angulosos a subangulosos. Estas brechas de arenitos possuem fragmentos com dimensões entre 5 e 25 centímetros, envoltos por material muito fino de composição argilosa e coloração avermelhada. O elevado grau de alteração dos afloramentos limita a coleta de amostras dos arenitos, entretanto, a presença de uma matriz argilosa alterada de cor castanha avermelhado é sugestiva da ocorrência de material vítreo. Esta evidência remete a identificação de um material fundido (melt), sugerindo que as brechas de arenitos são brechas de impacto (Figs. 7a,b).

Formação Serra Geral Os basaltos da Formação Serra Geral apresentam cor castanha escura a preta, variando para castanho avermelhado-alaranjado quan- do alterados. Comumente apresentam textura porfirítica, com 10 a $20 \%$ de fenocristais de plagioclásio com forma prismática alongada, subédricos, com 1 a 3 milímetros, imersos em matriz equigranular muito fina a afanítica. A estrutura é maciça, com ocorrência subordinada de estrutura de fluxo marcada por um fraturamento relativamente contínuo e regular de disposição suborizontal, com espaçamento centimétrico (Fig. 8a). As porções de topo mostram zona amigdaloidal e/ou vesicular com espessura centimétrica a métrica, com estruturas de 1 a $5 \mathrm{~mm}$ de formas subarredondadas a amebóides, preenchidas por calcita, calcedônia e/ ou quartzo (Fig. 8b). No extremo sudeste da estrutura ocorrem autobrechas caracterizadas por fragmentos arredondados de basaltos vesiculares envoltos por matriz fina, por vezes apresentando dobramentos irregulares (Fig. 8c). As rochas vulcânicas situadas fora da região central da estrutura mostram muito baixo grau de fraturamento.

No extremo oeste do núcleo da estrutura do Jarau foi identificado um dique de diabásio com espessura aflorante de 10 metros. Possui cor cinza escura e está alterado, apresentando textura equigranular fina caracterizada por plagioclásio e minerais máficos, provavelmente piroxênio (Fig. 8d). Nos arredores do di-

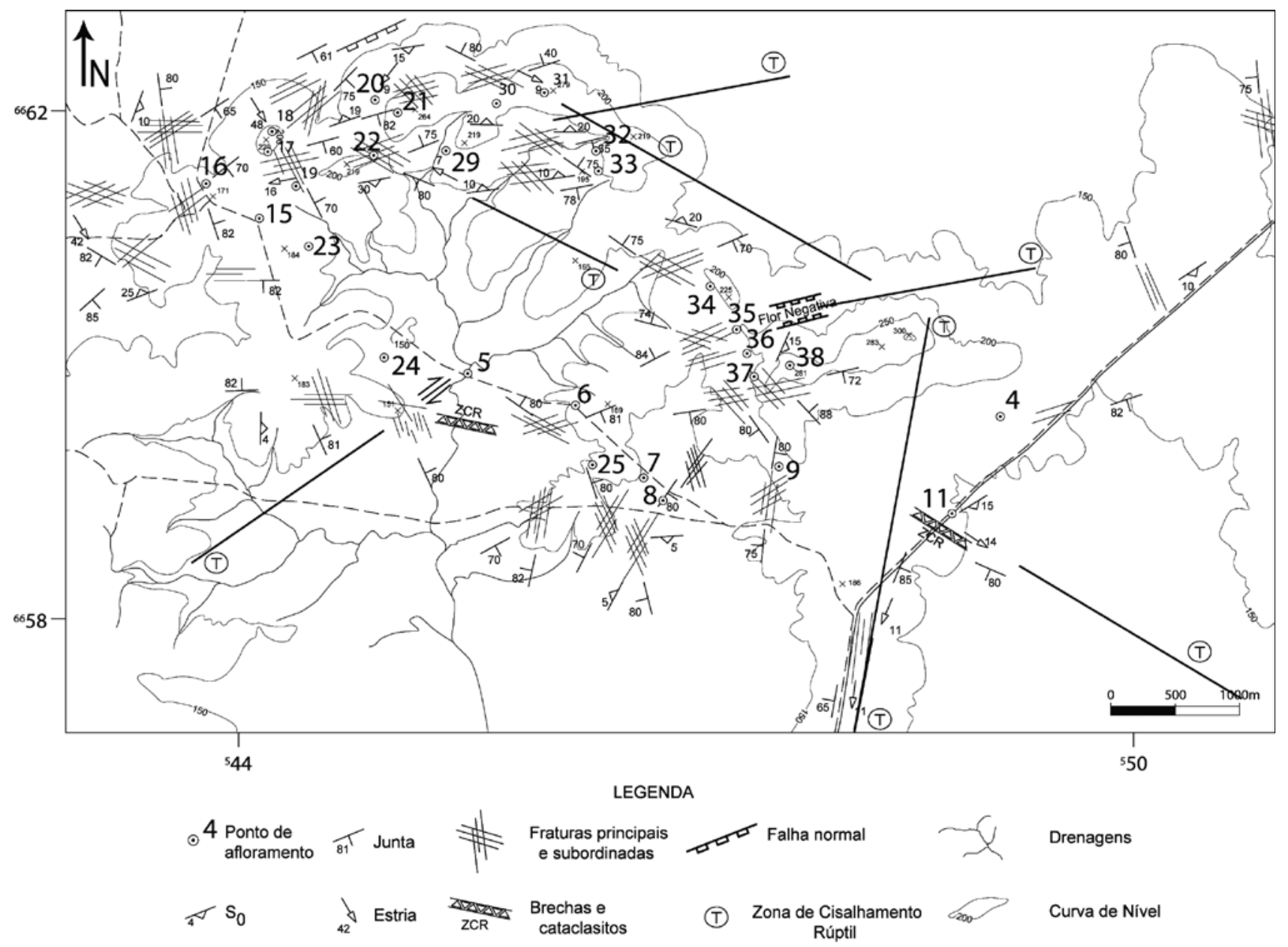

Figura 6 - Mapa estrutural com representação das principais estruturas coletadas nos trabalhos de campo. 

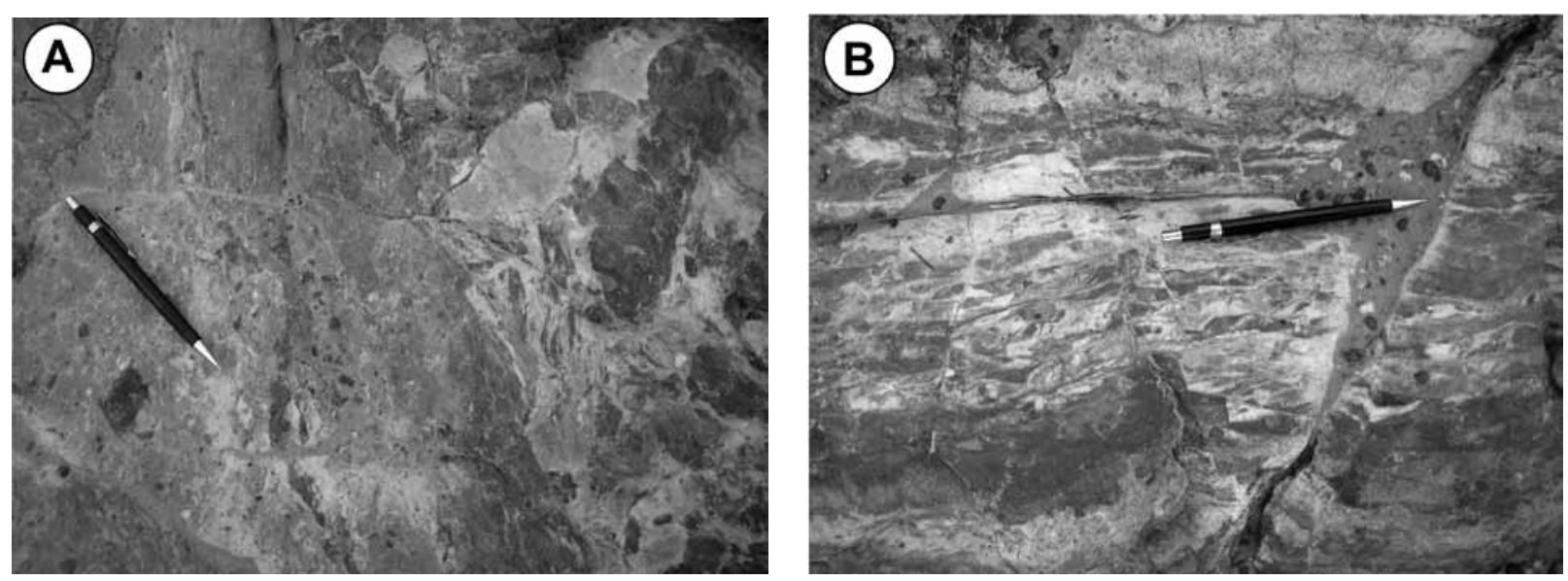

Figura 7 - Afloramento de arenitos alterados com estrutura brechada localizados na porção central da estrutura do Cerro do Jarau. a) Provável brecha de impacto caracterizada por fragmentos angulosos de arenitos com dimensões diversas envoltos por matriz argilosa de cor avermelhada possivelmente representando material vítreo (cor escura na foto). b) Intensa deformação e fragmentação do acamadamento primário do arenito.

que os arenitos encontram-se litificados e com coesão elevada, sugerindo a transferência de calor da intrusão para a encaixante. Este corpo pode ser correlacionável aos basaltos da Formação Serra Geral, que apresentam composição equivalente e ocorrem ao longo de toda a porção externa da estrutura do Cerro do Jarau. Não foi identificada em superfície, nenhuma outra ocorrência de rochas vulcânicas ou hipabissais, nas porções internas e de borda da estrutura.

As relações de contato entre os arenitos e os derrames basálticos foram observadas na porção leste da estrutura, onde foram descritas brechas vulcanoclásticas com uma disposição suborizontal e forma alongada. São constituídas por fragmentos angulosos a subangulosos de composição basáltica e dimensões variáveis entre 1 e 15 centímetros, cimentados por um material arenoso de composição quartzo-feldspática. Estes depósitos podem ser interpretados como peperitos ou peperitos-like e têm a sua gênese normalmente assumida como decorrente da interação entre a lava e os sedimentos ainda inconsolidados (Fig. 8e).

Em área mais distante da estrutura, ao longo da BR-377 e cerca de $15 \mathrm{~km}$ ao leste da cidade de Quaraí, também foram observados dois tipos de relações de contato entre a lava e os sedimentos. A primeira é caracterizada por impressões de lava em corda deixada nos arenitos, indicando a interação de lavas basálticas do tipo pahoehoe com sedimentos na porção superior de dunas eólicas. A outra relação observada é definida pela diminuição progressiva do espaçamento das juntas de resfriamento (diáclases) em direção ao contato com os sedimentitos (Fig. 8f).

GEOLOGIA ESTRUTURAL E MICROESTRUTURAS Os levantamentos geológicos foram concentrados na porção central e soerguida da estrutura, onde estão concentradas as principais feições deformacionais rúpteis. Na zona externa a este núcleo central, o grau de deformação e fraturamento é extremamente baixo. Na região central foram identificadas estruturas tectônicas de natureza rúptil, como falhas normais, zonas de cisalhamento transcorrentes rúpteis e um conjunto variado de juntas. Os dados estruturais foram distribuídos e analisados segundo quatro setores definidos como oeste, norte, leste e central, correspondendo respectivamente às porções aflorantes do núcleo soerguido do Cerro do Jarau.

A estrutura central do Cerro do Jarau está limitada, tanto na sua extremidade norte-noroeste, quanto na sua extremidade nordeste por zonas de falhas normais de direção média entre $\mathrm{N} 30-45^{\circ} \mathrm{E}$, com mergulhos de ângulo médio a subverticais para sudeste (Fig. 6). Estas falhas produzem superfícies lisas a curvilíneas, com estrias com caimento entre 50 e $75^{\circ}$. Relacionados a estas falhas normais encontram-se conjugados de fraturas com disposição aproximadamente subvertical (Fig. 9a).

Além destas estruturas são identificadas zonas de cisalhamento transcorrentes, de natureza rúptil, que cortam as rochas da estrutura segundo as direções N40$60^{\circ} \mathrm{W}, \mathrm{N} 60-80^{\circ} \mathrm{E}$ e $\mathrm{N} 10^{\circ} \mathrm{E}$, com mergulhos subverticais para NW e SE. Estas zonas apresentam superfícies retilíneas a curvilíneas, formando de modo mais srestrito, faixas de cataclasitos e brechas de esmagamento com espessuras centimétricas $(15$ a $50 \mathrm{~cm})$ geradas principalmente sobre os basaltos da Formação Serra Geral (Fig. 9b). Nos planos de máxima deformação são observadas estrias com caimento entre 4 e $15^{\circ}$, direcionadas para NE e SE e "steps" subverticais, indicativas de deslocamentos direcionais. Associado a estas estruturas ocorre intenso fraturamento, de espaçamento centimétrico a métrico e dispostos de modo aproximadamente concordante com as zonas de cisalhamento, constituindo conjugados de cisalhamento do tipo Riedel.

As estruturas primárias observadas nos arenitos, em especial os limites entre sets de estratificações cruza- 

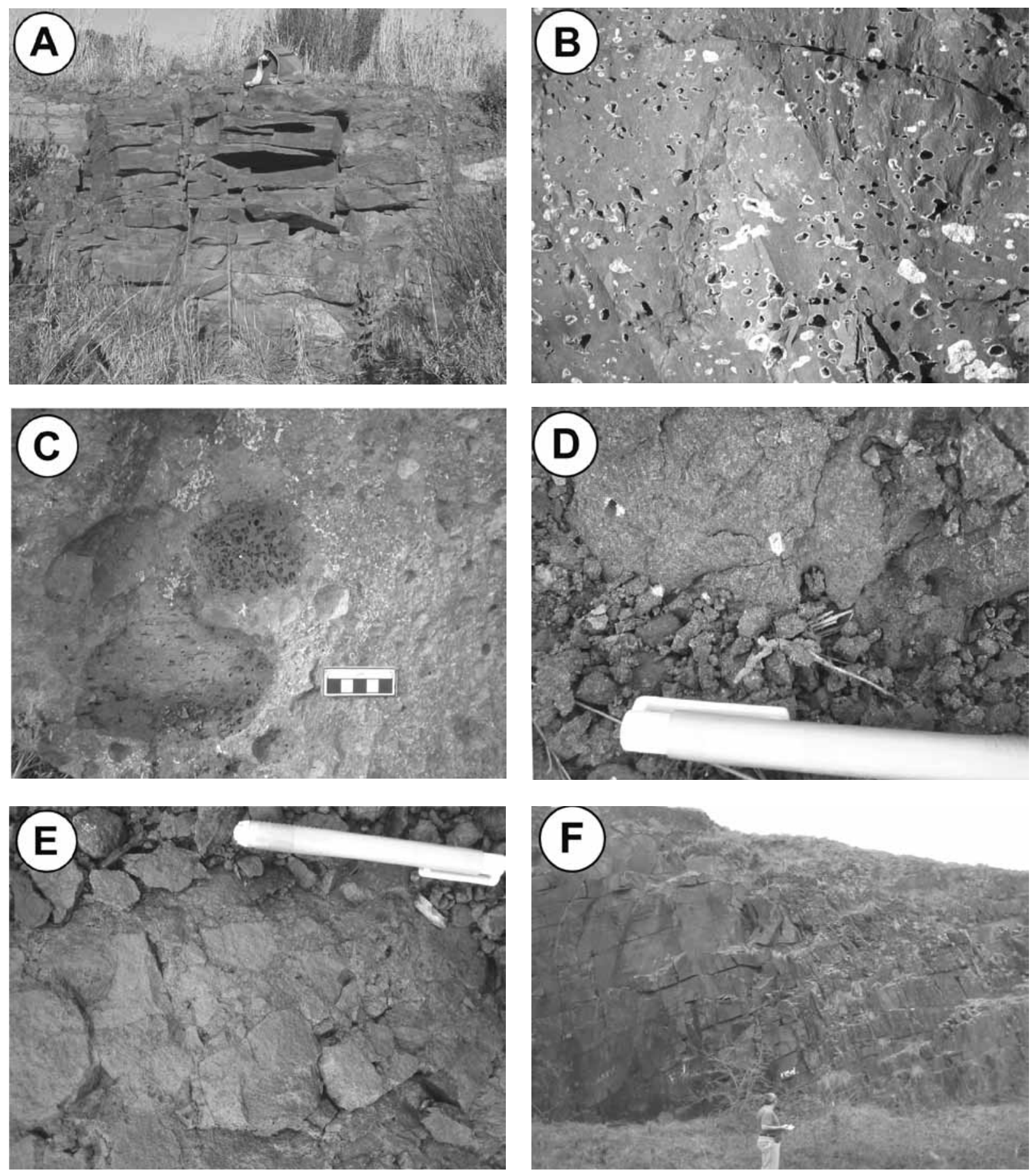

Figura 8 - Principais feições macroscópicas dos basaltos da Formação Serra Geral ocorrentes na porção externa da estrutura do Cerro do Jarau. A) Corte de estrada destacando a estrutura de fluxo magmático marcada por diaclasamento suborizontal; B) Textura vesicular e amigdaloidal definida por vazios parcialmente preenchidos por quartzo; C) Detalhe de autobrecha caracterizada por fragmentos de basalto vesicular; D) Aspecto macroscópico do dique de diabásio; E) Aspecto macroscópico das brechas do tipo peperito, caracterizadas por fragmentos angulosos de basalto alterado envoltos por matriz arenosa rica em quartzo; F) Corte de estrada destacando a diminuição do espaçamento das diáclases subverticais no basalto em direção ao contato com os arenitos da Formação Botucatu situados a direita da foto.

das de grande porte, são interpretadas aqui como representantes da estratificação original de deposição. A estrutura plano-paralela mostra-se muito perturbada por efeitos das estruturas tectônicas. Apresenta entretanto, uma orientação média $\mathrm{N} 50^{\circ} \mathrm{E}$, com mergulhos entre $10^{\circ}$ e $40^{\circ}$ para
SE e NW (Figs. 6 e 10). Estas variações de orientação e mergulho representam a interação entre as falhas normais de direção NE e, subordinadamente, pelas zonas de cisalhamento direcionais de direção NW e NE. Os mergulhos mais elevados e a zona de maior perturbação está asso- 

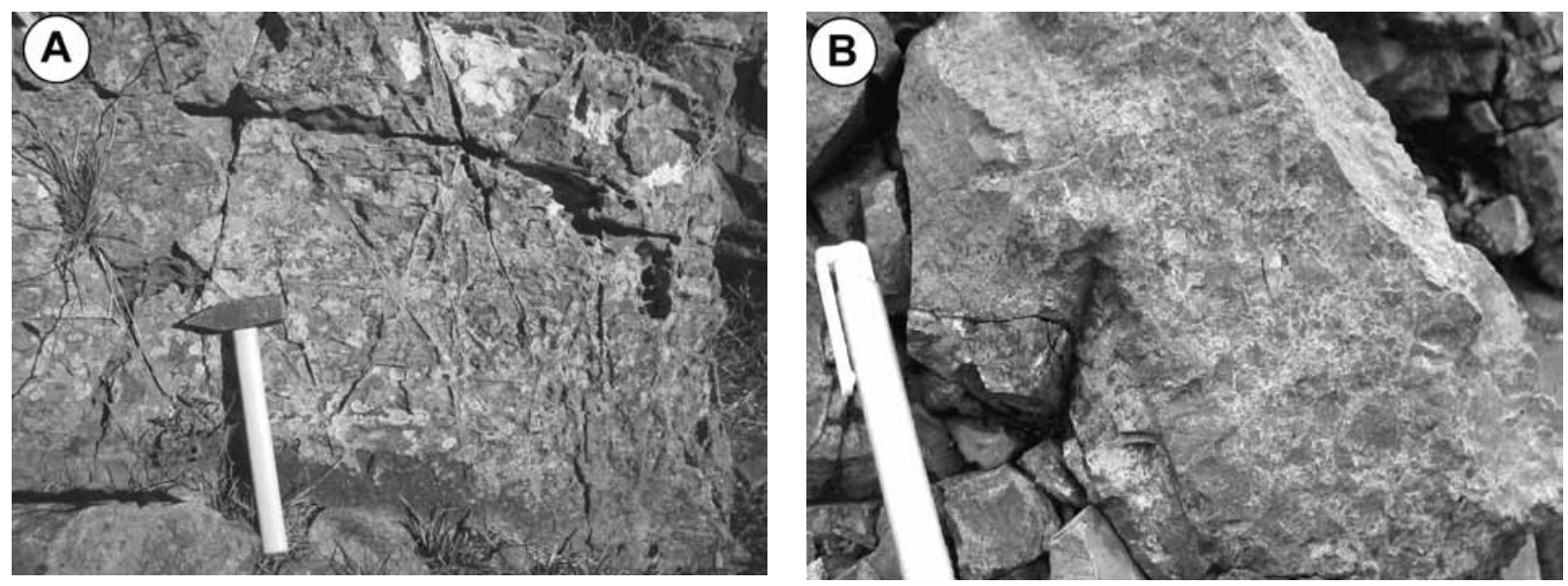

Figura 9 - Estruturas deformacionais rúpteis. A) Padrão de fraturamento dos arenitos da Formação Botucatu nas proximidades de falha extensional em crista localizada na porção oeste do núcleo da estrutura; B) Zona de cisalhamento rúptil localizada no extremo leste do núcleo do Jarau, mostrando cataclasitos sobre os basaltos da Formação Serra Geral.

ciada ao principal sistema de falha extensional que está situado na porção noroeste da estrutura do Jarau.

O processo de soerguimento do núcleo da estrutura do Cerro do Jarau está relacionado a uma etapa intermediária da evolução da cratera. Posterior ao choque do meteorito e ao colapso inicial da cratera, o alívio de pressão na porção de núcleo ocasionou a ascenção das rochas sedimentares da Formação Botucatu (Fig. 11). A ascenção do núcleo está vinculada com a geração, no entorno da porção central da cratera, de zonas de cisalhamento rúpteis, zonas de falhas extensionais e sistemas de fraturas associados. As bordas e a porção central mais rebaixada resultam da atuação de falhas extensionais, dispostas segundo dois sistemas aproximadamente ortogonais de direção $\mathrm{N} 20-45^{\circ} \mathrm{E}$ e $\mathrm{N} 30-60^{\circ} \mathrm{W}$, e que são responsáveis pela forma concêntrica da estrutura.

No setor oeste do núcleo soerguido ocorrem as principais falhas normais da estrutura, com direção de $\mathrm{N} 50-70^{\circ} \mathrm{E}$ e mergulhos entre 40 e $50^{\circ}$ para sudeste. As estrias de falha mostram caimento entre 40 e $60^{\circ}$ para sudeste (Fig. 12a). Também foram identificados dois conjuntos de zonas de cisalhamento direcionais discretas orientadas segundo as direções $\mathrm{N} 45^{\circ} \mathrm{E}$ e $\mathrm{N} 75^{\circ} \mathrm{E}$, com mergulhos subverticais para sudeste e noroeste (Fig. 6). Nestas zonas são observadas estrias de falha com baixo rake e caimento entre 5 e $15^{\circ}$ para NE e SW. As fraturas observadas neste setor são representadas por conjugados de fraturas de cisalhamento do tipo Riedel. Apresentam formas retilíneas a pouco curvilíneas e espaçamento entre $10-20 \mathrm{~cm}$ e $40 \mathrm{~cm}$ e $1 \mathrm{~m}$. Estas fraturas
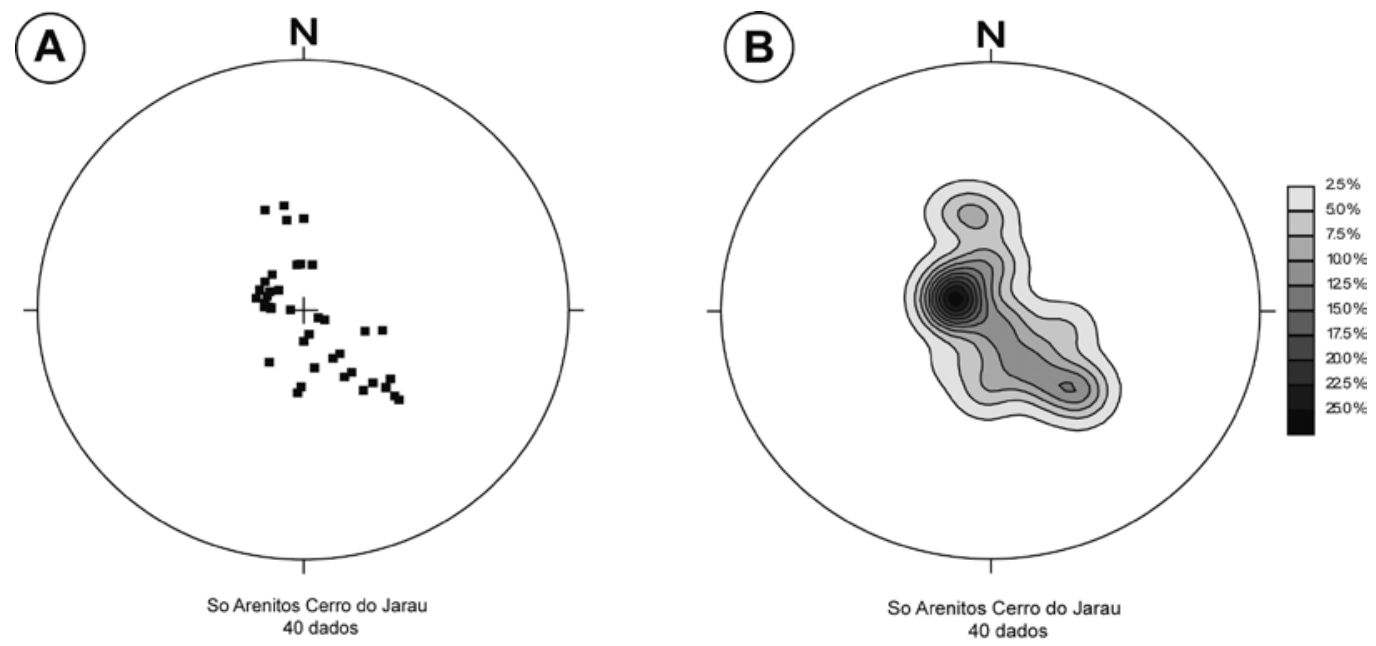

Figura 10 - Estereogramas de freqüencia (hemisfério inferior) representativos do acamadamento primário dos arenitos da Formação Botucatu localizados no núcleo da estrutura do Cerro do Jarau. a) Pólos do acamadamento; b) Diagrama de Kalsbeek com a contagem dos pólos. 

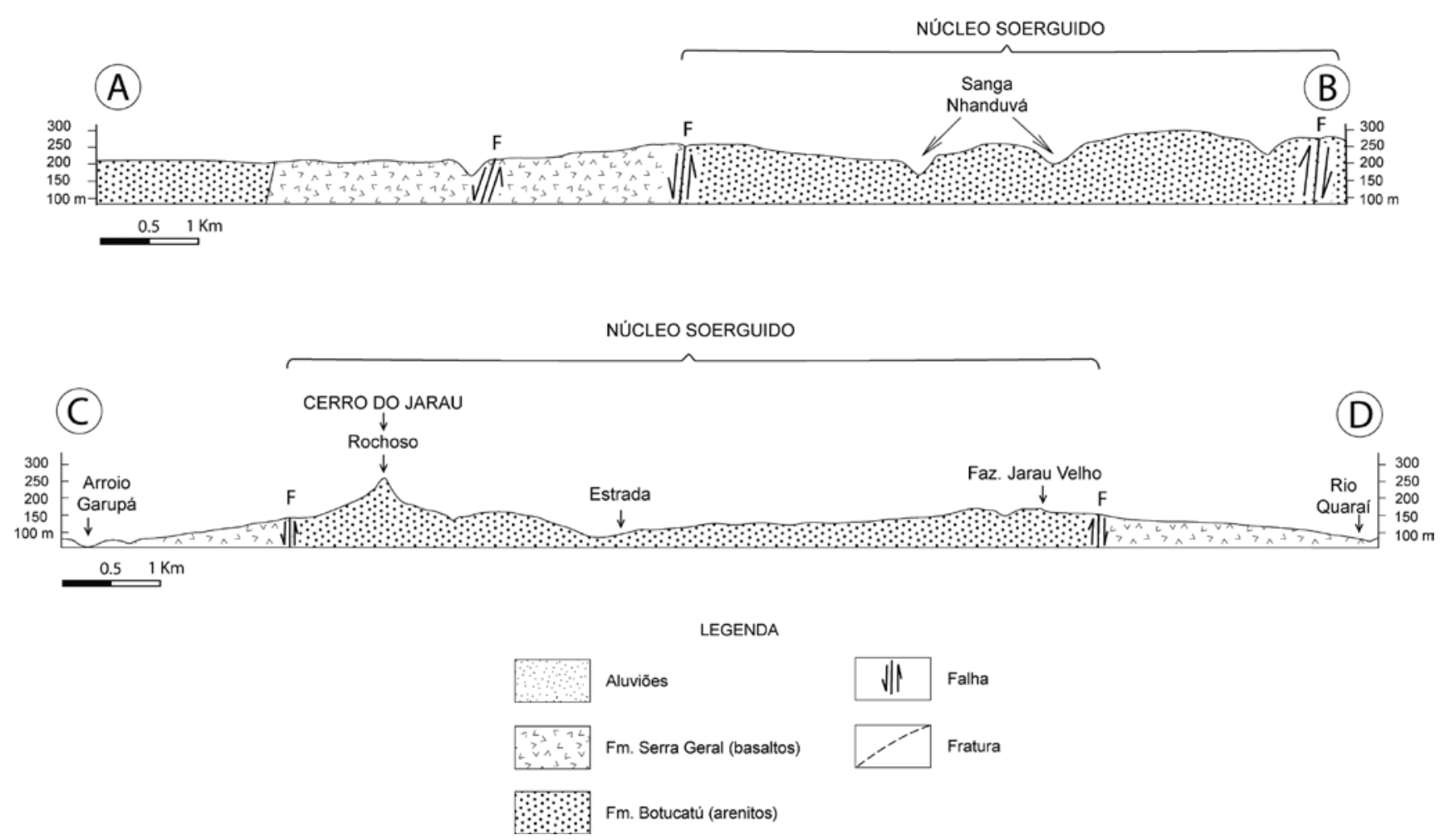

Figura 11 - Seções geológicas cortando a estrutura do Cerro do Jarau, destacando a presença de um núcleo soerguido representado uma janela estrutural.

apresentam direção média entre $\mathrm{N} 40-50^{\circ} \mathrm{E}$, com mergulhos elevados para SE e NW e estão representadas no estereograma de contagem de pólos de fraturas como duas áreas de concentração principal.

O setor norte da estrutura apresenta-se menos deformado que a porção oeste, com ocorrência localizada de zonas de cisalhamento direcionais de alto ângulo. As zonas possuem direção $\mathrm{N} 20^{\circ} \mathrm{E} ; 65 \mathrm{NW}$ e $\mathrm{N} 55^{\circ} \mathrm{W} ; 80 \mathrm{SE}$, com estrias de baixo rake e caimento entre 5 e $10^{\circ}$ para sudeste (Fig. 12b). Observa-se ainda uma falha normal, com disposição suborizontal, direção de $\mathrm{N} 20^{\circ} \mathrm{E}, 10^{\circ} \mathrm{SE}$ e estrias de alto rake direcionadas segundo $\mathrm{S} 80^{\circ} \mathrm{E}$. O padrão de fraturamento encontrado nos afloramentos desta área está associado com as zonas de cisalhamento transcorrentes e caracteriza-se por conjugados de fraturas de Riedel com direção média em torno de $\mathrm{N} 70^{\circ} \mathrm{W}$ e $\mathrm{N} 70^{\circ} \mathrm{E}$, com mergulhos elevados. O estereograma com contagem de pólos das fraturas mostra diversas concentrações, com predominância média de fraturas com direção $\mathrm{N} 80^{\circ} \mathrm{W}$ e mergulhos de $80^{\circ}$ para nordeste e, subordinadamente, de direção $\mathrm{N} 60^{\circ} \mathrm{E}$, com mergulhos de $40^{\circ}$ para noroeste. Neste setor são identificadas zonas com baixa densidade de fraturamento caracterizadas pela presença de lineações com disposição curvilínea e orientações variadas ao longo dos planos de fraturas, principalmente na área abrangida pelos pontos 20, 21, 22 e 29 do mapa estrutural. Estas características podem sugerir que estas lineações sejam cones de estilhaçamento (shatter cones) pouco desenvolvidos (Fig. 13).

$\mathrm{O}$ setor leste apresenta intenso fraturamento e elevada concentração de zonas de cisalhamento direcionais. Foram identificadas zonas de cisalhamen- to com três orientações, onde a principal tem direção $\mathrm{N} 45-50^{\circ} \mathrm{W}$, com mergulhos subverticais para NW e NE. As estrias de falha mostram caimento entre $10^{\circ}$ e $14^{\circ}$ para sudeste (Fig. 14a). De modo subordinado ocorrem outros dois conjuntos de zonas de cisalhamento discretas orientadas segundo a direção $\mathrm{N} 10^{\circ} \mathrm{E}-\mathrm{N} 10^{\circ} \mathrm{W} \mathrm{N} 40^{\circ} \mathrm{E}$ e $\mathrm{N} 70^{\circ} \mathrm{W}$, com mergulhos subverticais para SE e NW, respectivamente. Nestas zonas são observadas estrias de falha com baixo rake, e caimento de 5 a $15^{\circ}$ para sul. As fraturas observadas neste setor são representadas por conjugados de fraturas de cisalhamento do tipo Riedel, que se concentram em duas direções médias de $\mathrm{N} 45^{\circ} \mathrm{W}$ e $\mathrm{N} 60^{\circ} \mathrm{E}$, com mergulhos elevados para SE e NW. As fraturas tem formas retilíneas a pouco curvilíneas, superfícies lisas e espaçamento entre 10 e $40 \mathrm{~cm}$.

O setor central da estrutura apresenta um relevo plano, com grande preservação de estruturas primárias e evidências mais localizadas de deformação, essencialmente marcadas por zonas de fraturas com espaçamento métrico a decamétrico (entre 1 e 10 metros). As fraturas são retilíneas a curvilíneas e mostram superfície lisa. Ocorrem duas zonas de falhas direcionais na porção central, orientadas segundo as direções $\mathrm{N} 60^{\circ} \mathrm{E}$; $80 \mathrm{SE}$ e N70 ${ }^{\circ} \mathrm{W}$, com disposição subvertical (Fig. 14b). Não se obteve estrias devido à elevada alteração intempérica e pelo fato dos afloramentos ao longo do arroio Nhanduvaí serem do tipo lajeado. Entretanto, observa-se deslocamento entre as camadas plano-paralelas do arenito e também a formação de faixas de rochas com aspecto cataclástico e/ou brechóide (Fig.7 e 15). Esta brecha é monomítica foi identificada no ponto 5 (Fig. 6) e contém clastos angulosos de quartzo-arenito 


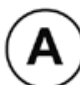

A)

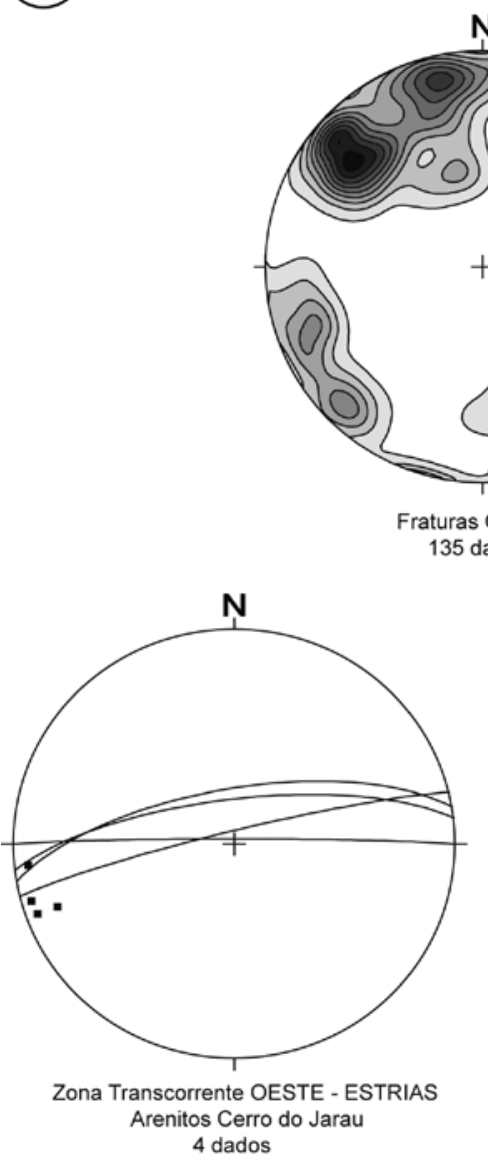

(B)
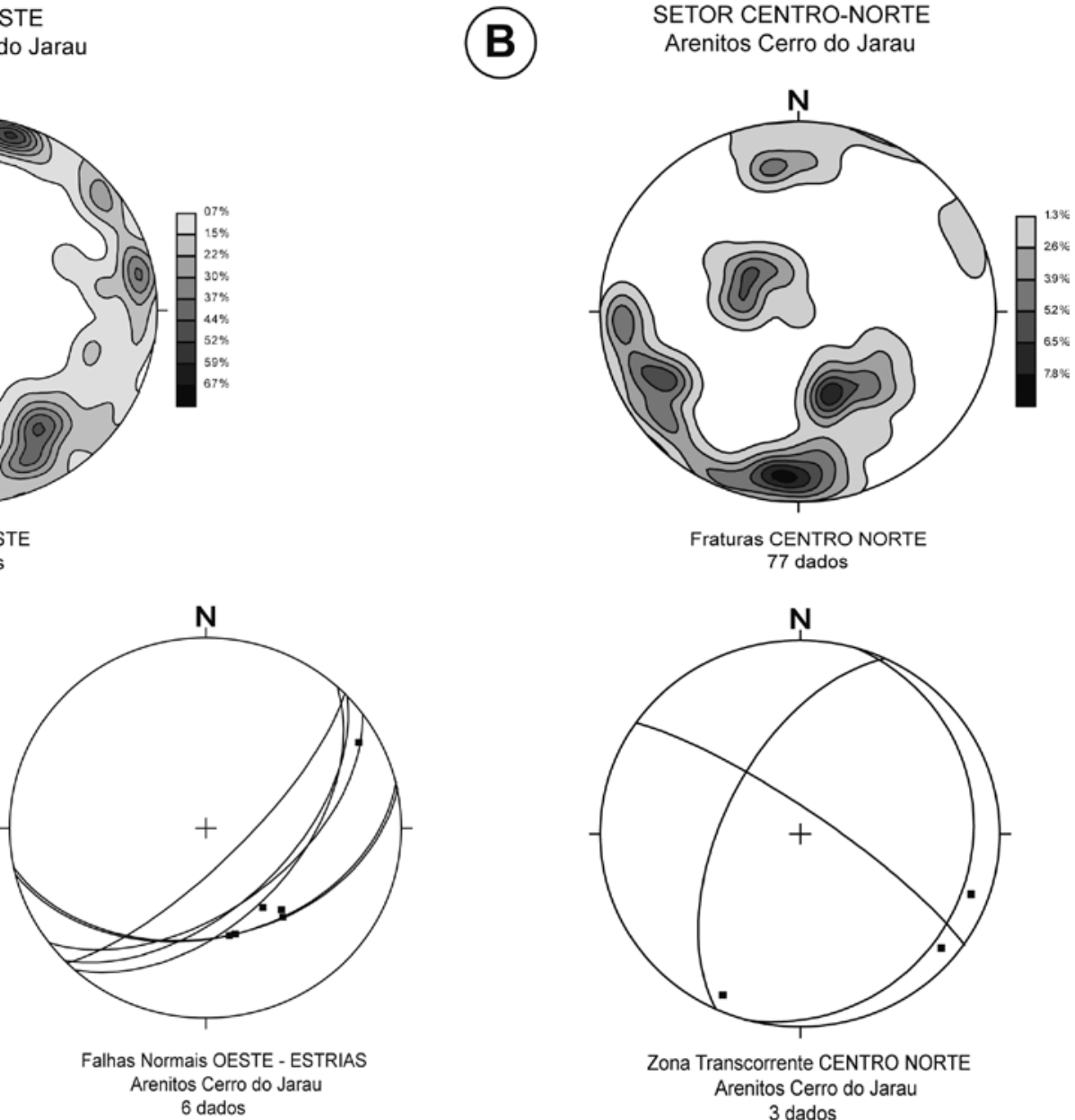

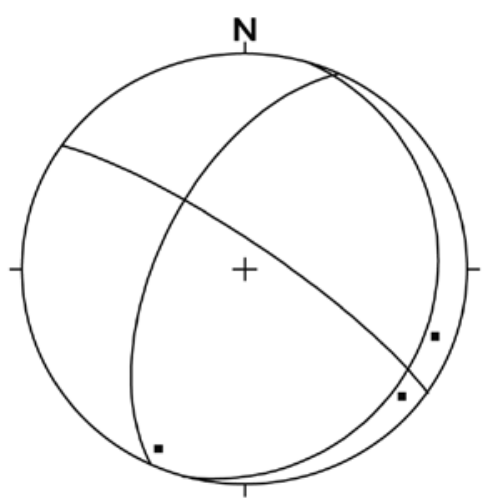

Zona Transcorrente CENTRO NORTE Arenitos Cerro do Jarau

Figura 12 - Estereogramas de freqüência (hemisfério inferior) representativos das principais estruturas rúpteis encontradas no núcleo do Cerro do Jarau. A Concentração dos pólos de fraturas; zonas de cisalhamento e lineações da crista de arenitos representativa da porção oeste da estrutura; B) Concentração dos pólos de fraturas, zonas de cisalhamento e lineações da crista representativa da porção norte do núcleo da estrutura do Jarau.

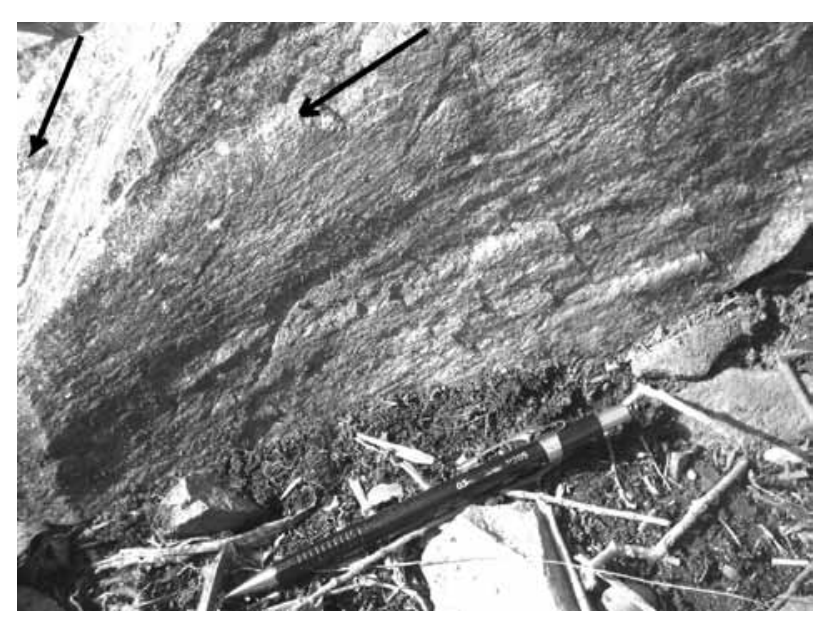

Figura 13 - Estruturas lineares com disposição curvilinea e direção variável, semelhantes a shatter cones ocorrentes nos arenitos da Formação Botucatu. de dimensões centiméricas ( 2 a $10 \mathrm{~cm}$ ) envoltos por uma matriz argilosa de cor avermelhada. A matriz destas "brechas" está alterada e sugere pelo seu contexto que estas rochas possam representar brechas de injeção, onde o material vítreo injetado está alterado pelo intemperismo.

A observação das lâminas delgadas de arenitos da porção interna da estrutura do Jarau apontou feições petrográficas indicativas de estruturas de impacto. Os cristais de quartzo das amostras coletadas nos pontos 5 e 35 mostram lamelas de deformação e apresentam microestruturas (fraturas) com disposição retilínea e dispostas em duas a três direções distintas. As feições de deformação planares encontradas na amostra do ponto 5 , caracterizadas por 3 sets paralelos de planos de deformação com espaçamento diminuto, são sugestivas de feições do tipo PDFs (planar deformation features) (Fig. 16a). Estas feições são causadas pela passagem da onda de choque na estrutura cristalina do quartzo, gerando feições planares de disposição paralela aos principais planos cristalográficos dos cristais de quartzo, 
(A)
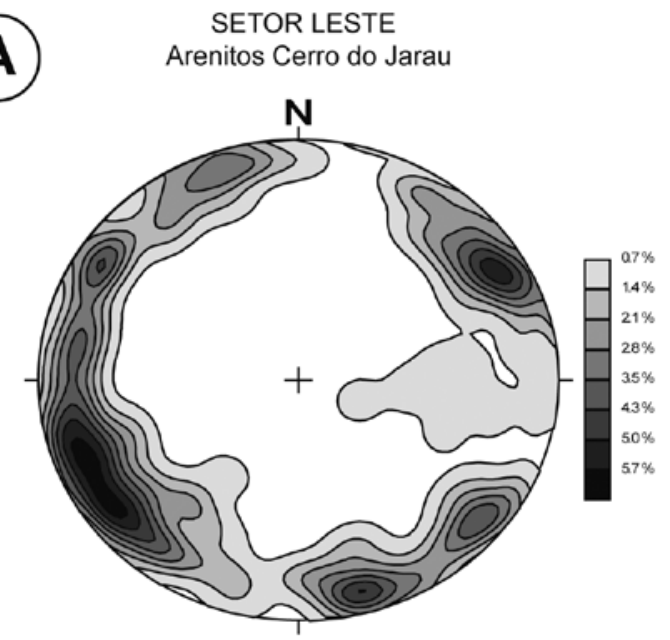

Fraturas LESTE

141 dados

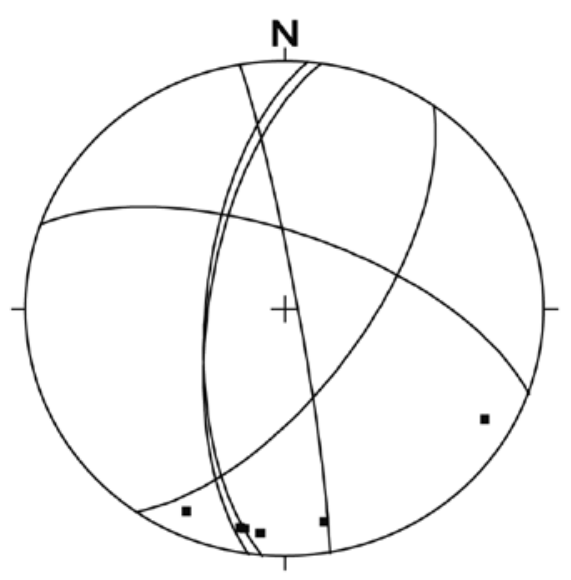

Zona Transcorrente LESTE e Estrias Arenitos Cerro do Jarau 6 dados

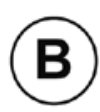

SETOR CENTRO

Arenitos Cerro do Jarau

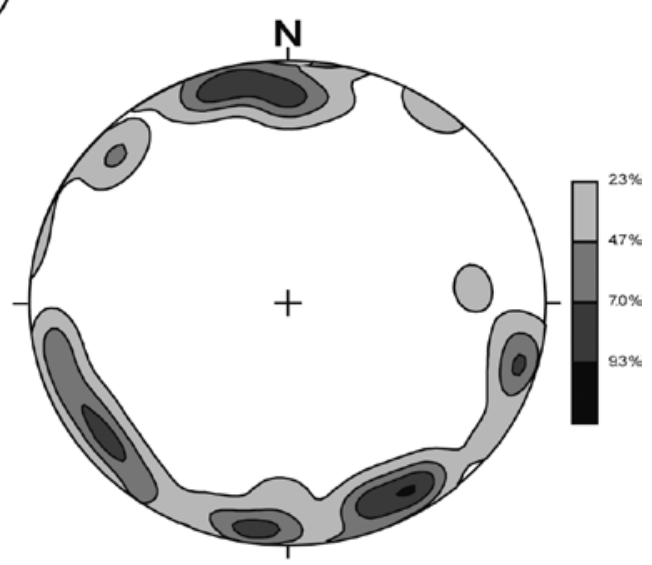

Fraturas CENTRO

43 dados

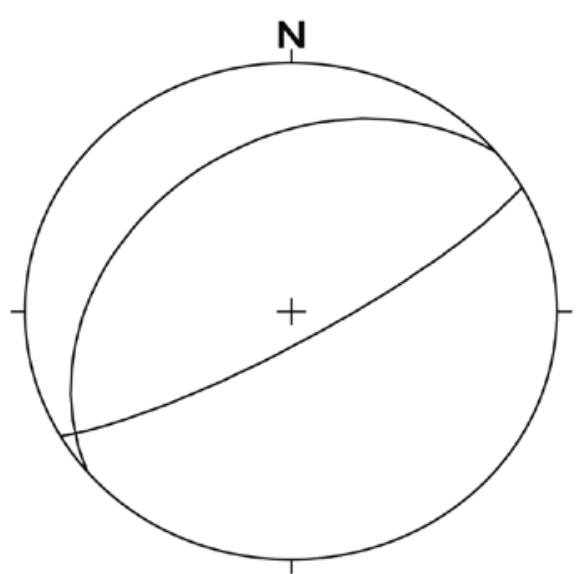

Zona Transcorrente CENTRO

Arenitos Cerro do Jarau 2 dados

Figura 14a

Figura 14 - Estereogramas de freqüência (hemisfério inferior) representativos das principais estruturas rúpteis encontradas no núcleo do Cerro do Jarau. A) Concentração de pólos de fraturas; zonas de cisalhamento e lineações da crista representativa da porção leste da estrutura do Jarau; B) Pólos de fraturas, zonas de cisalhamento e lineações representativas da porção central da estrutura do Jarau.

paralelos ao eixo C (0001) e aos planos romboédricos (French 1998; French \& Koeberl 2010). Na amostra do ponto 35 , as feições de deformação geram sets de planos paralelos, entretanto em números mais reduzidos, mais descontínuos e com espaçamento maior entre os planos de deformação (Fig. 16b). Desta maneira, as feições da amostra do ponto 35 são semelhantes as denominadas PFs (planar fractures), que são estruturas causadas pela passagem de ondas de choque de baixo impacto e geradas sob condições mais amenas de pressão $(<10 \mathrm{GPa})$.

DISCUSSÃO Os levantamentos geológicos demonstraram pelas relações de contato entre as rochas vulcânicas e os arenitos que ambas as unidades tiveram uma evolução final conjunta, ocorrendo interação entre as lavas e os arenitos. A coesão elevada dos arenitos pode

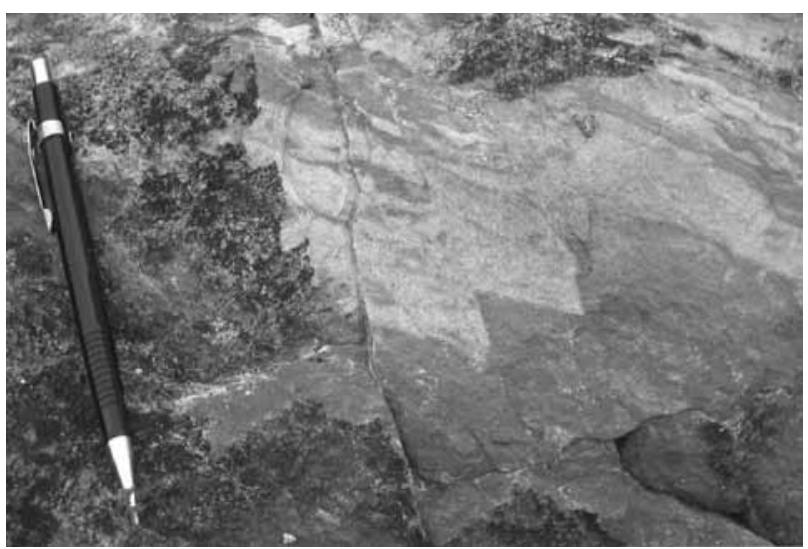

Figura 15 - Vista em planta de afloramento de arenito da Formação Botucatu na porção central da estrutura destacando pequenos deslocamentos ao longo de zonas de fraturas elou falhas transcorrentes. 

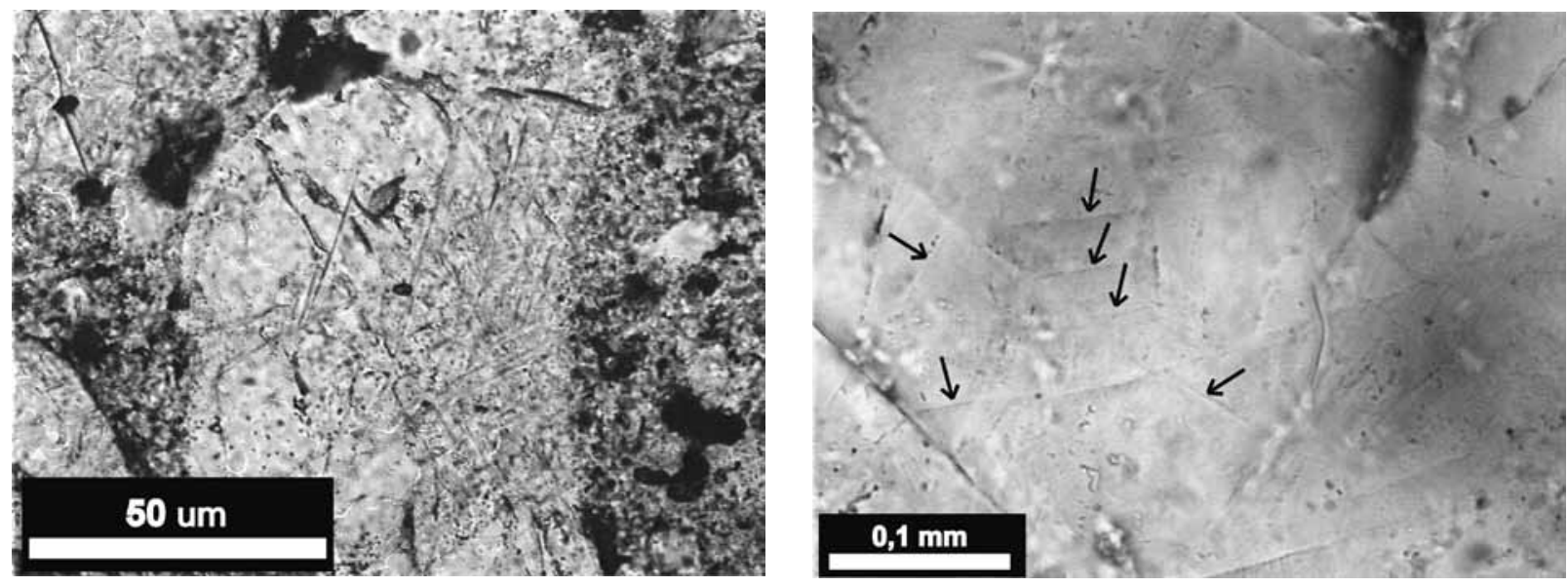

Figura 16 - Feições de deformação planar do tipo PDF's e PF's em cristais de quartzo dos arenitos da porção centro-leste do Cerro do Jarau. a) Cristal de quartzo envolto por matriz brechada destacando a presença de PDF's de três direções principais de planos de deformação retilíneas; b) Detalhe em cristal de quartzo límpido mostrando as três direções de planos de deformação do tipo PF's destacadas por setas pretas.

ser explicada pela expressiva cimentação quartzosa. Os dados petrográficos sugerem que os arenitos próximos ao contato com os basaltos sofreram efeitos restritos de diagênese e, portanto, a precipitação do cimento de calcedônia e quartzo deve ter sido catalisada pela circulação de voláteis e pelo desprendimento de calor da própria lava. Na porção mais central do núcleo os arenitos não apresentam esta coesão elevada, entretanto, esta área é deprimida topograficamente e encontra-se em geral, mais fraturada e alterada intempericamente.

Nos trabalhos de campo executados neste estudo a disposição do acamadamento plano-paralelo original dos sedimentitos da porção central da estrutura indica uma direção geral nordeste $\left(\mathrm{N} 40-60^{\circ} \mathrm{E}\right)$ com mergulhos muito suaves $\left(<10^{\circ}\right)$ para sudeste e noroeste. Esta variação sugere uma disposição dômica e mostra que o acamadamento original está basculado para direções variadas e foi afetado pelas estruturas rúpteis de maior escala.

A presença na porção central da estrutura de rochas estratigraficamente sotopostas indica que a estruturação do Cerro do Jarau foi responsável pelo alçamento das rochas subjacentes. O grau de fraturamento e a geração de estruturas rúpteis estão concentrados nas porções internas da estrutura do Cerro do Jarau, sugerindo desta forma, que esta porção foi submetida a taxas elevadas de deformação quando comparada com as porções externas. A forma circular, associada com a intensa deformação da porção central, embora não diagnósticas, são feições de campo características de uma estrutura de impacto conforme ressaltado por French (1998) e French \& Koeberl (2010).

A tectônica dominante no interior da estrutura é de natureza rúptil e dominantemente extensional. As estruturas subordinadas estão caracterizadas por conjugados de fraturas de cisalhamento e pela presença de zonas de cisalhamento transcorrentes rúpteis discretas. Estas últimas estruturas não apresentam um padrão regular de disposição espacial, demonstrando pelo menos três direções distintas de orientação espacial perfazen- do um padrão aproximadamente radial. O grau e fraturamento (intensidade e número de fraturas) é elevado na porção central da estrutura e muito baixo na porção externa do núcleo soerguido. O conjunto destas informações sugere que este conjunto de estruturas provavelmente foi originado pelo impacto de um meteorito na porção central do Cerro do Jarau.

As fraturas do tipo PDFs (planar deformational features) e PFs associadas (planar features) encontradas nos grãos de quartzo do arenito também são indicativas do impacto. Estas microestruturas planares são interpretadas como produto de taxas elevadas de deformação compatíveis com as geradas pelo impacto de corpos celestes (Koeberl 1994; French 1998; Crosta 2002; Kenkmann et al. 2005; Koeberl et al. 2005a,b; Crosta et al. 2005; French \& Koeberl 2010). French (1998) e French \& Koeberl (2010) destacam que as fraturas PDFs em quartzo é a feição petrográfica mais ampla, distinguível e aceita para caracterizar o impacto de meteoritos.

A estrutura do Cerro do Jarau foi afetada por processos de erosão diferencial e somente a porção norte do núcleo soerguido da cratera está parcialmente preservada. A presença de PDF's, a inexistência de fragmentos de rocha ejetados e de brechas de impacto nas porções externas, bem como a erosão da borda sul da cratera são indicativos que o grau erosão é profundo. Este fato ainda pode ser reforçado pela ausência de brechas de fusão na porção central da estrutura, bem como pelo padrão circular com intensa deformação e brechação dos arenitos que ocorrem na porção central da estrutura.

CONCLUSÕES O padrão circular observado nas imagens de satélite e fotografias aéreas, associado com os dados petrográficos e estruturais sugerem que a estrutura alçada do Cerro do Jarau apresenta uma evolução complexa e resulta do impacto de um meteorito. Este processo foi responsável pelo complexo padrão 
espacial apresentado pelas estruturas rúpteis observadas e pelo soerguimento do núcleo, com os afloramentos de arenitos da Formação Botucatu caracterizando uma janela estratigráfica e estrutural. A interação das zonas de falhas normais e transcorrentes de direção NW-SE e NE-SW resultou no soerguimento do núcleo, que constitui a estrutura circular principal, com relação aos blocos abatidos que perfazem as áreas mais baixas e adjacentes. O principal sistema de falhas é extensional e apresenta direção média $\mathrm{N} 40^{\circ} \mathrm{W}$ e resulta numa estrutura alçada do tipo HORST.

A presença de uma intensa tectônica rúptil e deformadora concentrada na porção central da estrutura, a ocorrência de prováveis brechas de impacto e de injeção e de cristais de quartzo com microestruturas do tipo PDF's e PF's são as principais evidências que sugerem que a estrutura circular do Cerro do Jarau foi causada pelo impacto de um meteorito. $\mathrm{O}$ resultado da complexa interação entre a deformação do impacto resultou no desenvolvimento de uma tectônica rúptil com a geração de zonas de falhas normais e zonas de cisalhamento rúpteis transcorrentes. A intersecção entre as estruturas frágeis e a modelação do relevo por erosão foram responsáveis pelo atual estágio de evolução da estrutura do Cerro do Jarau, caracterizada como a porção muito profunda de uma cratera de impacto. Parte da tectônica deformadora da estrutura circular do Cerro do Jarau ainda pode estar associada com processos tectônicos mais recentes, de idade Terciária, responsáveis pela ocorrência de rochas kimberlíticas e lamproíticas aflorantes nas regiões de Rosário do Sul, Alegrete, Jaguari e outras localidades próximas. Novos estudos futuros deverão incrementar o nível de informações dirimir as incertezas ainda existentes sobre a evolução da geologia regional.

Agradecimentos Os autores agradecem a Arafértil Mineração Ltda. pelo suporte financeiro que permitiu a realização dos trabalhos de campo e laboratório, ao $\mathrm{CNPq}$ (processos No 309232/2003-1, de Ruy Paulo Philipp e 306616/2006-8, de Carlos Augusto Sommer) pela concessão de bolsa de produtividade. Ao prof. Dr. Luis Fernando de Ros (IG-UFRGS) pelas discussões e sugestões e aos revisores anônimos da RBG pelas críticas e importantes sugestões ao texto final.

\section{Referências}

French B.M. 1998. Traces of Catastrophe: A handbook of Shock-Metamorphic Effects in Terrestrial Meteorite Impact Structures. LPI Contribution $n^{\circ}$ 954, Houston, Lunar and Planetary Institute, $120 \mathrm{p}$.

French B.M. \& Koeberl C. 2010. The convincing identification of terrestrial meteorite impact structures: what works, what doesn't, and why. Earth Science Rewievs, 98:123-170.

Gastal M.C.P., Lafon J.M., Ferreira F.J.F., Magro F.H.S., Remus M.V.D., Sommer C.A. 2006. Reinterpretação do Complexo Intrusivo Lavras do Sul, RS, de acordo com os sistemas vulcano-plutônicos de subsidência. Parte 1: geologia, geofísica e geocronologia $\left({ }^{207} \mathrm{~Pb} /{ }^{206} \mathrm{~Pb}\right.$ e $\left.{ }^{206} \mathrm{~Pb} /{ }^{238} \mathrm{U}\right)$. Revista Brasileira de Geociências, 36:109124.

Grehs, S.A. 1969. Aspectos Geológicos e Geomorfológicos do Cerro do Jarau, Rio Grande do Sul. In: SBG, Congresso Brasileiro de Geologia, 23, Anais, p. 265-272.

Hausman A. 1966. Comportamento do freático nas áreas basálticas do Rio Grande do Sul. Boletim Paranaense de Geografia, 18-20:187-205.

Horbach R., Kuck L., Marimon R.G., Moreira H.L., Fuck G.F., Moreira M.L.D., Marimon M.P.C., Pires J.L., Vivian D., Marinho D., Teixeira W. 1986. Folha SH.22 Porto Alegre e parte das folhas SH.21 Uruguaiana e SI.22 Lagoa Mirim, Geologia, IBGE, Levantamento de Recursos Naturais, 33:29-312.

Kenkmann T., Jahn A., Scherler D., Ivanov B.A. 2005. Structure and formation of central uplift: a case study at the Upheaval Dome impact crater, Utah. Geological Society of America Special Paper, 384:85-115.

Koeberl C. 1994. African meteorite impact craters: characteristics and geological importance. Journal of African
Earth Sciences, 18:263-295.

Koeberl C., Reimold W.U., Cooper G., Cowan D., Vincent P. 2005a. Aorounga and Gweni Fada impact structures, Chad: remote sensing, petrography and geochemistry of target rocks. Meteoritics and Planetary Science, 40:1-17.

Koeberl C., Reimold W.U., Plescia J. 2005b. BP and Oasis impact structures, Lybia: remote sensing and fields studies. In: Koeberl C. \& Henkel H. (eds.) Impact Tectonics. Berlin, Springer, p.161-190.

Leonardos O.H., Gibson S.A., Thompsom R.N., Leonardos Jr. O.H. 1994. The Serra Bueno potassic diatreme: a possible hypoabysal ultramafic alkaline volcanics in the Alto Parnaiba Igneous Province, SE, Brazil. Mineralogical Magazine, 58:357-372.

Lima E.F. (1995). Petrologia das rochas vulcânicas e hipabissais da Associação Shoshonítica de Lavras do Sul-ASLS, $R S$. Porto Alegre, Tese de Doutoramento, Universidade Federal do Rio Grande do Sul, 338 p.

Lisboa N.A. 1990. Aspectos morfoestruturais e geomorfológicos do extremo sul-ocidental do Planalto Meridional, Quaraí, RS. Ciência e Natura, 12:105-109.

Lisboa N.A., Oliveira M.T.G., Schuck M.T.G.O., Eick N.C., Carraro C.C. 1985. Identificacão de uma estrutura tectônica elíptica na Formacão Serra Geral, RS, através de imagens Landsat, Radar e Aerofotos. In: SBG, Simpósio Sul Brasileiro de Geologia, 2, Anais, 1:131-145.

Lisboa N.A., Oliveira M.T.G., Schuck M.T.G.O., Tramontina H.C. 1987. Reconhecimento geológico da região do Jarau, Quarai, RS. In: SBG, Simpósio Sul Brasileiro de Geologia, 3, Atas, 1:319-332.

Lisboa N.A. \& Schuck M.T.G.O. 1988. Caracterização de formas e padrões estruturais no Grupo São Bento da Bacia do Paraná no Rio Grande do Sul em imagens orbitais 
e suborbitais. In: SBG, Simpósio Brasileiro de Sensoriamento Remoto, Anais, 2:323-333.

Liz J.D., Lima E.F., Nardi L.V.S., Hartmann L.A., Sommer C.A., Gonçalves C.R.H. 2004. Aspectos petrográficos e composicionais do sistema multi-intrusivo da Associação Shoshonítica de Lavras do Sul (RS) e seu potencial para mineralizações de ouro e sulfetos. Revista Brasileira de Geociências, 34:539-552.

Moreira H.L., Freitas P.R.S., Nunes A.B. 1980. Geologia da estrutura de colapso do Jarau. In: SBG, Congresso Brasileiro de Geologia, 31, Anais, 5:2684-2690.

Morris R.H. 1963. Geologia geral das quadrículas Gravatai, Taquara e Rolante, RS, Brasil. Revista da Escola de Geologia, UFRGS, Publicação especial no 5, 38p.

Philipp R.P., Viero A.P., Comin-Chiaramonti P., Gomes C.B. 2005. Mesozoic alkaline rocks of Rio Grande do Sul, Brazil. In: Comin-Chiaramonti P. \& Gomes C.B. (eds.) Mesozoic to Cenozoic Alkaline Magmatism in the Brazilian Platform. São Paulo, Editora da Universidade de São Paulo/FAPESP, p.573-590.

Rolim S.B.A., Philipp R.P., Sommer C.A. 2007. Reavaliação do Modelo de Impacto para a Estrutura do Cerro do Jarau, RS. In: Congresso Uruguayo de Geología, 5, Anales, 1:45.

Rolim S.B., Philipp R.P., Souza C.R. (submetido). Interpretation of gravity and aeromagnetic anomalies of the Cerro do Jarau structure, Quaraí, RS, South Brazil. Revista Brasileira de Geofísica.

Scheibe L.F., Furtado S.M.A., Comin-Chiaramonti P., Gomes C.B. 2005. Cretaceous alkaline magmatism from Santa Catarina state, southern Brazil. In: Comin-Chiaramonti P. \& Gomes C.B. (eds.) Mesozoic to Cenozoic Alkaline Magmatism in the Brazilian Platform. São Paulo, Editora da Universidade de São Paulo/FAPESP, p.523-572.

Scherer C.M.S. 1998. Análise estratigráfica e faciológica da Formação Botucatu (Neocomiano) no Estado do Rio
Grande do Sul. Tese de Doutorado, Instituto de Geociências, Universidade Federal do Rio Grande do Sul, 208p.

Scherer C.M.S. \& Lavina E. 2006. Stratigraphic evolution of a fluvial-eolian succession: The example of Upper Jurassic-Lower Cretaceous Guará and Botucatu formations, Paraná Basin, Southernmost Brazil. Gondwana Research, 9:475-484.

Schobbenhaus C., Campos D.A., Queiroz E.T., Winge M., Berbert-Born M.L.C. (ed.) 2002. Sitios Geológicos e Paleontológicos do Brasil. Brasília, DNPM/CPRM, Comissão Brasileira de Sítios Geológicos e Paleobiológicos (SIGEP), 554 p.

Schuck M.T.G.O. \& Lisboa N.A. 1987. Identificação de padrões estruturais no Grupo São Bento, Quarai, RS, através de imagens orbitais e suborbitais. Revista Pesquisas, 20:5-24.

Sommer C.A. 1994. O Vulcanismo Ácido Alcalino da Porção Sul do Platô do Taquarembó, Dom Pedrito - RS. Porto Alegre, Dissertação de Mestrado, Instituto de Geociências, UFRGS, 203 p.

Tedesco M.A. \& Robaina L.E.S. 1991. Caracterização geoquímica de piroxênios e granadas da brecha kimberlítica de São Vicente - RS. In: SBGq, Congresso Brasileiro de Geoquímica, 1 e Congresso de Geoquímica dos Países de Língua Portiguesa, 1, São Paulo, Anais, 1:707-710.

Zolinger I.T., Svisero D.P., Weska R.K. 2002. Morfologia cristalina dos diamantes provenientes das Chapadas dos Guimarães, Poxoréu, Paranatinga, Diamantino e Alto Paraguai, MT. Revista do Instituto Geológico, 23:23-33.

Weska R.K. \& Svisero D.P. 2001. Aspectos geológicos de algumas intrusões kimberlíticas da região de Paranatinga, MT. Revista Brasileira de Geociências, 31:555-561.

Manuscrito ID 13450

Submetido em 09 de fevereiro de 2009 Aceito em 20 de outubro de 2010 